\title{
Review \\ Therapeutic Agents for Oxaliplatin-Induced Peripheral Neuropathy; Experimental and Clinical Evidence
}

\author{
Takehiro Kawashiri ${ }^{1} *{ }^{\mathbb{D}}$, Keisuke Mine ${ }^{1}$, Daisuke Kobayashi ${ }^{1}$, Mizuki Inoue ${ }^{1}$, Soichiro Ushio ${ }^{2}$, \\ Mayako Uchida $^{3}$, Nobuaki Egashira ${ }^{4}(\mathbb{D})$ and Takao Shimazoe ${ }^{1}$ \\ 1 Department of Clinical Pharmacy and Pharmaceutical Care, Graduate School of Pharmaceutical Sciences, \\ Kyushu University, Fukuoka 812-8582, Japan; mine.keisuke.035@s.kyushu-u.ac.jp (K.M.); \\ dkobayas@med.kyushu-u.ac.jp (D.K.); inoue.mizuki.049@s.kyushu-u.ac.jp (M.I.); \\ shimazoe@phw.med.kyushu-u.ac.jp (T.S.) \\ 2 Department of Pharmacy, Okayama University Hospital, Okayama 700-8558, Japan; s-ushio@okayama-u.ac.jp \\ 3 Education and Research Center for Clinical Pharmacy, Osaka University of Pharmaceutical Sciences, \\ Osaka 569-1094, Japan; mayaco@gly.oups.ac.jp \\ 4 Department of Pharmacy, Kyushu University Hospital, Fukuoka 812-8582, Japan; \\ n-egashi@pharm.med.kyushu-u.ac.jp \\ * Correspondence: tkawa@med.kyushu-u.ac.jp; Tel.: +81-92-642-6573
}

Citation: Kawashiri, T.; Mine, K.; Kobayashi, D.; Inoue, M.; Ushio, S.; Uchida, M.; Egashira, N.; Shimazoe, T. Therapeutic Agents for OxaliplatinInduced Peripheral Neuropathy; Experimental and Clinical Evidence. Int. J. Mol. Sci. 2021, 22, 1393.

https://doi.org/10.3390/ijms22031393

Academic Editor:

Marialessandra Contino

Received: 30 December 2020

Accepted: 27 January 2021

Published: 30 January 2021

Publisher's Note: MDPI stays neutral with regard to jurisdictional claims in published maps and institutional affiliations.

Copyright: (c) 2021 by the authors. Licensee MDPI, Basel, Switzerland. This article is an open access article distributed under the terms and conditions of the Creative Commons Attribution (CC BY) license (https:// creativecommons.org/licenses/by/ $4.0 /)$.

\begin{abstract}
Oxaliplatin is an essential drug in the chemotherapy of colorectal, gastric, and pancreatic cancers, but it frequently causes peripheral neuropathy as a dose-limiting factor. So far, animal models of oxaliplatin-induced peripheral neuropathy have been established. The mechanisms of development of neuropathy induced by oxaliplatin have been elucidated, and many drugs and agents have been proven to have neuroprotective effects in basic studies. In addition, some of these drugs have been validated in clinical studies for their inhibitory effects on neuropathy. In this review, we summarize the basic and clinical evidence for the therapeutic effects of oxaliplatin. In basic research, there are many reports of neuropathy inhibitors that target oxidative stress, inflammatory response, sodium channel, transient receptor potential (TRP) channel, glutamate nervous system, and monoamine nervous system. Alternatively, very few drugs have clearly demonstrated the efficacy for oxaliplatin-induced peripheral neuropathy in clinical trials. It is important to activate translational research in order to translate basic research into clinical research.
\end{abstract}

Keywords: oxaliplatin; peripheral neuropathy; preclinical data; clinical evidence; adverse effects

\section{Introduction}

Oxaliplatin is a platinum-based chemotherapeutic agent that is widely used as a standard treatment for colorectal, gastric, and pancreatic cancers, usually combined with other therapeutic agents such as fluorouracil, irinotecan, capecitabine, or tegafur, gimeracil and oteracil, however it often causes severe peripheral neuropathy. Within a few hours to a few days after oxaliplatin administration, acute neuropathy, such as cold sensory disturbance in the limbs and perioral region, appears. In most cases, cold-related acute neuropathy is transient and reversible $[1,2]$. In addition, sensory deficits as chronic neuropathy, a dose-limiting factor, occur after repeated oxaliplatin administration [2,3]. These neuropathies remain a significant clinical problem with oxaliplatin chemotherapy because they can affect quality of life and lead to drug reductions or discontinuation. Previous reports have suggested that voltage-gated ion channels and transient receptor potential channels are involved in oxaliplatin-induced acute neuropathy [4-6]. Chronic neuropathy is thought to be caused by morphological changes in neurons, such as axonal degeneration and damage to neuronal cell bodies [7-9]. However, no drugs have been recommended to prevent chemotherapy-induced peripheral neuropathy [10]. Since around 2000, animal models of chemotherapy-induced peripheral neuropathy, including oxaliplatin-induced 
neuropathy, have been established and reported [11-13]. In this study, we reviewed the preclinical and clinical evidence for oxaliplatin-induced peripheral neuropathy.

\section{Therapeutic Agents in Preclinical Evidence}

All articles found in PubMed with the search term "oxaliplatin neuropathy or oxaliplatin neurotoxicity" were surveyed. The last search date was 1 August 2020. Reports that did not include information on therapeutic agents for oxaliplatin-induced peripheral neuropathy and clinical studies were excluded from the analysis. From the surveyed papers, we extracted information on the name and dosage of the drugs that showed statistically significant improvement, their mechanism of action, and the animal species in which they were used.

There were 1657 articles in PubMed for the search term "oxaliplatin neuropathy or oxaliplatin neurotoxicity". Of these, 127 articles reported on drugs that inhibit oxaliplatininduced peripheral neuropathy in animal studies. The following is a summary of the drugs had therapeutic effects on oxaliplatin-induced peripheral neuropathy in these basic studies (Table 1). 
Table 1. The therapeutic agents for oxaliplati-induced peripheral neuropathy in preclinical experiments.

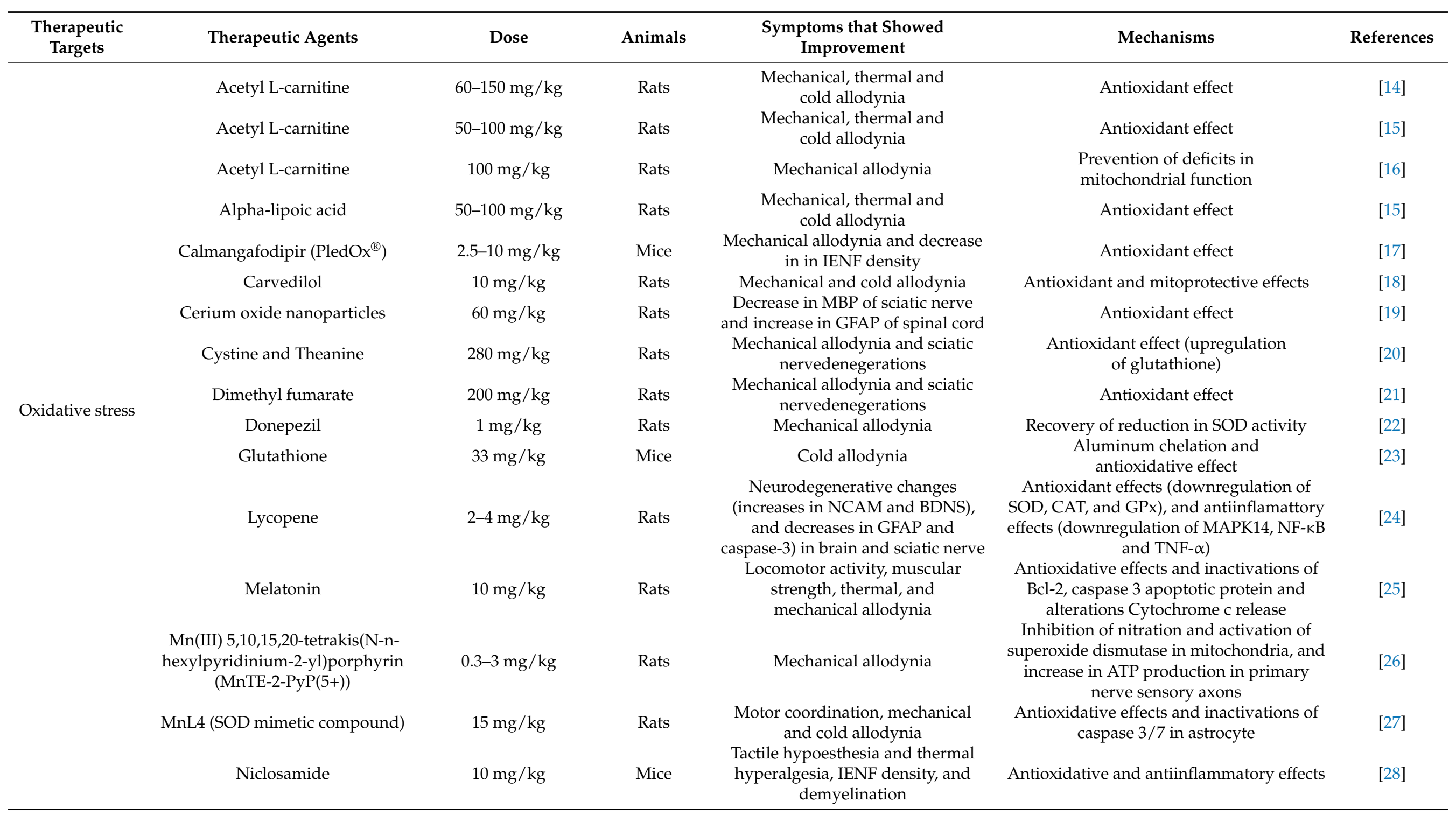


Table 1. Cont.

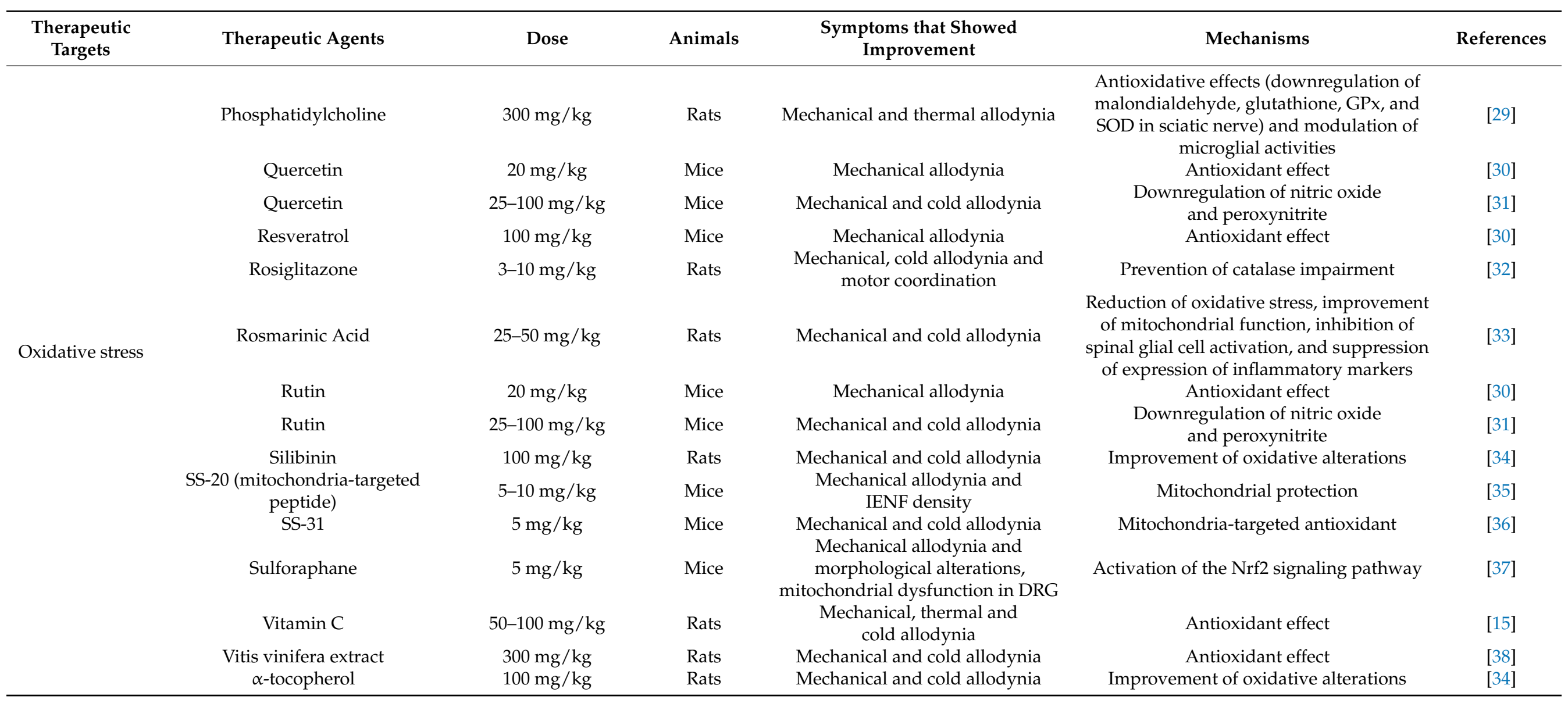


Table 1. Cont.

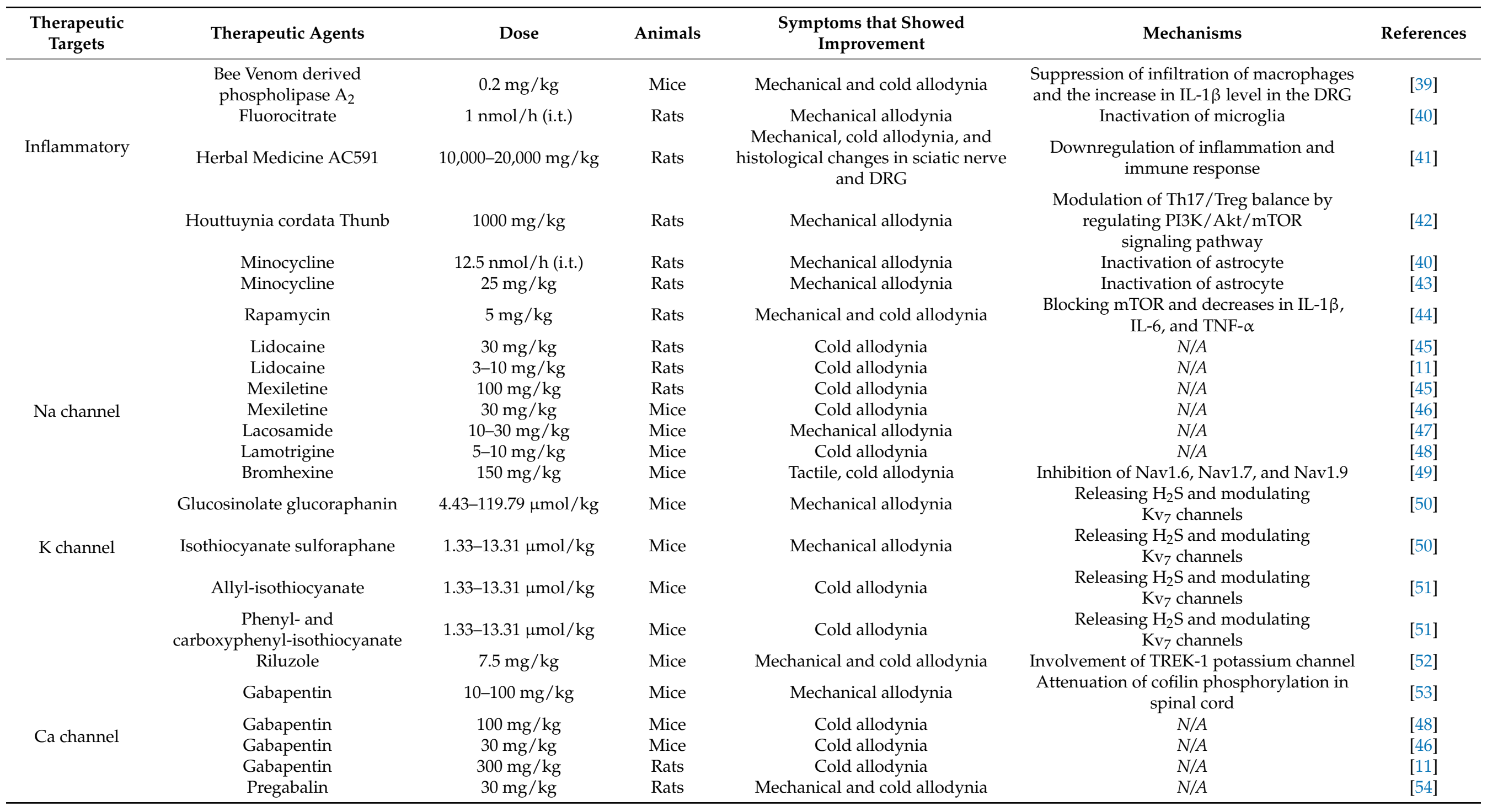


Table 1. Cont.

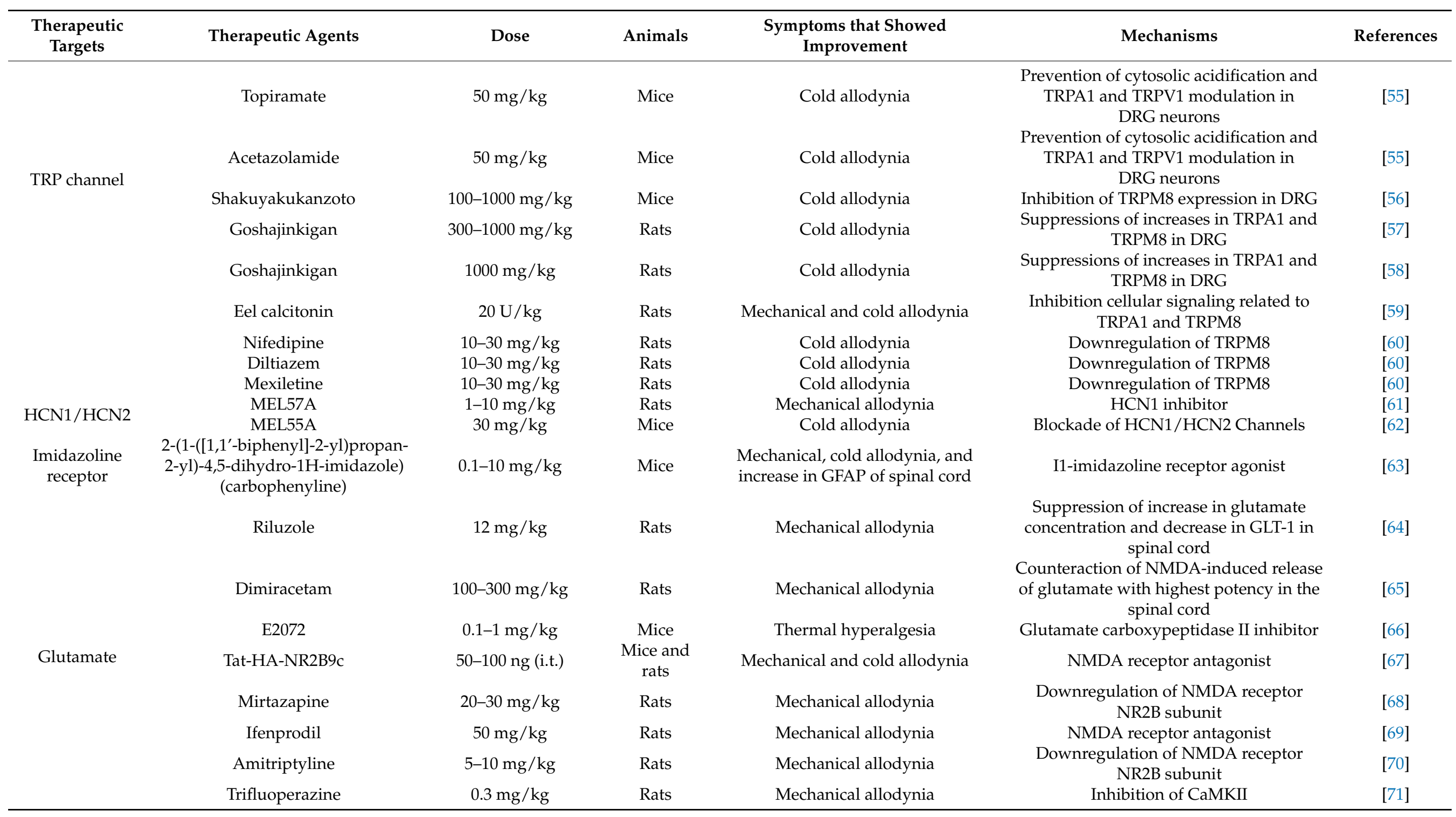


Table 1. Cont.

\begin{tabular}{|c|c|c|c|c|c|c|}
\hline $\begin{array}{l}\text { Therapeutic } \\
\text { Targets }\end{array}$ & Therapeutic Agents & Dose & Animals & $\begin{array}{l}\text { Symptoms that Showed } \\
\text { Improvement }\end{array}$ & Mechanisms & References \\
\hline \multirow[t]{2}{*}{ PDE } & Tadalafil & $10 \mathrm{mg} / \mathrm{kg}$ & Mice & $\begin{array}{l}\text { Cold, mechanical, and electrical } \\
\text { current hypersensitivities, and } \\
\text { thermal hypoesthesia. }\end{array}$ & $\begin{array}{l}\text { Increases in blood flow and } \\
\text { skin temperature }\end{array}$ & [72] \\
\hline & Ibudilast & $7.5 \mathrm{mg} / \mathrm{kg}$ & Rats & Mechanical allodynia & $N / A$ & [73] \\
\hline $\begin{array}{l}\text { Endothelin } \\
\text { receptor }\end{array}$ & Bosentan & $100 \mathrm{mg} / \mathrm{kg}$ & Mice & $\begin{array}{l}\text { Mechanical and thermal } \\
\text { hypersensitivity }\end{array}$ & $\begin{array}{l}\text { Antagonism of endothelin ETA and } \\
\text { ETB receptors }\end{array}$ & {$[74]$} \\
\hline \multirow{5}{*}{$\begin{array}{l}\text { Cannabinoid } \\
\text { receptor } \\
\text { Sigma-1 } \\
\text { receptor }\end{array}$} & Cannabidiol & $1.25-10 \mathrm{mg} / \mathrm{kg}$ & Mice & Mechanical allodynia & $N / A$ & {$[75]$} \\
\hline & E-52862 & $20-80 \mathrm{mg} / \mathrm{kg}$ & Rats & Cold allodynia & Sigma-1 receptor antagonist & [76] \\
\hline & SA4503 & $3 \mathrm{mg} / \mathrm{kg}$ & Rats & Mechanical allodynia & Sigma-1 receptor agonist & [77] \\
\hline & Fentanyl & $0.017-0.03 \mathrm{mg} / \mathrm{kg}$ & Rats & Mechanical and cold allodynia & $N / A$ & [78] \\
\hline & LOR17 ( $\mathrm{k}$-opioid receptor agonist) & $1-20 \mathrm{mg} / \mathrm{kg}$ & Rats & Cold allodynia & K-opioid receptor agonist & [79] \\
\hline \multirow{9}{*}{ Opioid receptor } & Morphine & $1-3 \mathrm{mg} / \mathrm{kg}$ & Rats & Mechanical and cold allodynia & N/A & [78] \\
\hline & Oxycodone & $0.3-0.56 \mathrm{mg} / \mathrm{kg}$ & Rats & Mechanical and cold allodynia & $N / A$ & [78] \\
\hline & Tramadol & $20 \mathrm{mg} / \mathrm{kg}$ & Mice & Cold allodynia & $N / A$ & [46] \\
\hline & Tramadol & $30 \mathrm{mg} / \mathrm{kg}$ & Rats & Cold allodynia & $N / A$ & [80] \\
\hline & Amitriptyline & $2.5-10 \mathrm{mg} / \mathrm{kg}$ & Mice & Cold allodynia & $N / A$ & [81] \\
\hline & Bee venom acupuncture & $0.25-2.5 \mathrm{mg} / \mathrm{kg}$ & Mice & Mechanical and cold allodynia & $\begin{array}{c}\text { Activations of spinal opioidergic and } \\
5-\mathrm{HT}_{3} \text { receptors }\end{array}$ & [83] \\
\hline & Bee venom acupuncture & $0.25-1 \mathrm{mg} / \mathrm{kg}$ & Rats & Cold allodynia & Activation of the noradrenergic system & [84] \\
\hline & $\begin{array}{l}\text { Bee Venom derived } \\
\text { phospholipase } A_{2}\end{array}$ & $0.2 \mathrm{mg} / \mathrm{kg}$ & Mice & Mechanical and cold allodynia & $\begin{array}{l}\text { Activation of the noradrenergic system, via } \\
\qquad \alpha_{2} \text {-adrenegic receptors }\end{array}$ & [85] \\
\hline & Clomipramine & $2.5 \mathrm{mg} / \mathrm{kg}$ & Rats & Cold allodynia & $N / A$ & [11] \\
\hline \multirow[t]{7}{*}{ Monoamines } & Clonidine & $0.1 \mathrm{mg} / \mathrm{kg}$ & Mice & $\begin{array}{l}\text { Mechanical allodynia and spinal } \\
\text { p-p38 MAPK expression }\end{array}$ & $\alpha_{2}$ adrenoceptor agonist & [86] \\
\hline & Duloxetine & $30-60 \mathrm{mg} / \mathrm{kg}$ & Mice & Mechanical and cold allodynia & Activating spinal $\alpha_{1}$-adrenergic receptor & [87] \\
\hline & Duloxetine & $30 \mathrm{mg} / \mathrm{kg}$ & Rats & Cold allodynia & $N / A$ & [80] \\
\hline & Duloxetine & $2.5 \mathrm{mg} / \mathrm{kg}$ & Mice & Cold allodynia & $N / A$ & [88] \\
\hline & Fluoxetine & $20 \mathrm{mg} / \mathrm{kg}$ & Rats & Mechanical and cold allodynia & Blockade serotonergic $5-\mathrm{HT}_{2 \mathrm{C}}$ receptor & [89] \\
\hline & $\begin{array}{l}\text { Melittin (major content of bee } \\
\text { venom) }\end{array}$ & $0.5 \mathrm{mg} / \mathrm{kg}$ & Mice & Mechanical and cold allodynia & $\begin{array}{c}\text { Activating the spinal } \alpha_{1} \text {-and } \\
\alpha_{2} \text {-adrenergic receptors. }\end{array}$ & {$[90]$} \\
\hline & Morphine & $2-5 \mathrm{mg} / \mathrm{kg}$ & Mice & Mechanical and cold allodynia & $\begin{array}{l}\text { Activations of spinal opioidergic and } \\
\text { 5- } \mathrm{HT}_{4} \text { receptors }\end{array}$ & [83] \\
\hline
\end{tabular}


Table 1. Cont.

\begin{tabular}{|c|c|c|c|c|c|c|}
\hline $\begin{array}{l}\text { Therapeutic } \\
\text { Targets }\end{array}$ & Therapeutic Agents & Dose & Animals & $\begin{array}{l}\text { Symptoms that Showed } \\
\text { Improvement }\end{array}$ & Mechanisms & References \\
\hline \multirow{5}{*}{ Monoamines } & NLX-112 & $0.1-5 \mathrm{mg} / \mathrm{kg}$ & Mice & Mechanical allodynia & $5-\mathrm{HT}_{1 \mathrm{~A}}$ receptor agonist & [91] \\
\hline & Pregabalin & $30 \mathrm{mg} / \mathrm{kg}$ & Rats & Cold allodynia & N/A & [80] \\
\hline & Tandospirone & $1-3 \mathrm{mg} / \mathrm{kg}$ & Mice & $\begin{array}{l}\text { Mechanical allodynia and mast } \\
\text { cell migration }\end{array}$ & $5-\mathrm{HT}_{1 \mathrm{~A}}$ receptor agonist & [93] \\
\hline & Venlafaxine & $7.5 \mathrm{mg} / \mathrm{kg}$ & Rats & Cold allodynia & $N / A$ & [11] \\
\hline & Xaliproden & $0.3-3 \mathrm{mg} / \mathrm{kg}$ & Mice & $\begin{array}{l}\text { Mechanical allodynia and mast } \\
\text { cell migration }\end{array}$ & $5-\mathrm{HT}_{1 \mathrm{~A}}$ receptor agonist & [93] \\
\hline \multirow{5}{*}{$\begin{array}{l}\text { Acetylcholine } \\
\text { receptor }\end{array}$} & $\begin{array}{c}\text { Citicoline } \\
\text { (cytidine-5'-diphosphate- choline; } \\
\text { CDP-choline) }\end{array}$ & $1-2 \mu \mathrm{mol}$ (i.c.v.) & Rats & Mechanical allodynia & $\begin{array}{c}\text { Involvement of } \alpha 7 \mathrm{nAChRs,} \mathrm{and} \\
\text { interaction between GABAergic and } \\
\text { cholinergic system }\end{array}$ & [95] \\
\hline & (R)-ICH3 & $30 \mathrm{mg} / \mathrm{kg}$ & Rats & Mechanical and cold allodynia & $\alpha 7 \mathrm{nAChR}$ agonist & [96] \\
\hline & PNU-282987 & $30 \mathrm{mg} / \mathrm{kg}$ & Rats & Mechanical and cold allodynia & $\alpha 7 \mathrm{nAChR}$ agonist & [96] \\
\hline & $\alpha$ O-Conotoxin GeXIVA 1,2 & $32-128 \mathrm{mg} / \mathrm{kg}$ & Rats & Mechanical and cold allodynia & Antagonism of the $\alpha 9 \alpha 10 \mathrm{nAChR}$ & [97] \\
\hline & $\alpha$-conotoxin RgIA & 2-10 nmol (i.m.) & Rats & $\begin{array}{l}\text { Mechanical, cold allodynia, and } \\
\text { morphological changes of DRG }\end{array}$ & $\alpha 9 \alpha 10 \mathrm{nAChR}$ antagonist & [98] \\
\hline OCT2 & Dasatinib & $15 \mathrm{mg} / \mathrm{kg}$ & Mice & Mechanical allodynia & $\begin{array}{l}\text { Inhibition of platinum accumulation } \\
\text { via OCT2 }\end{array}$ & [99] \\
\hline OCTN1 & Ergothioneine & $15 \mathrm{mg} / \mathrm{kg}$ & Rats & Mechanical allodynia & $\begin{array}{l}\text { Inhibition of OCTN1 and decrease in } \\
\text { platinum accumulation in DRG neurons. }\end{array}$ & {$[100]$} \\
\hline \multirow{3}{*}{$\begin{array}{l}\text { Orexin receptor } \\
\text { Histamine } \\
\text { receptor }\end{array}$} & Orexin-A & $0.1-1 \mathrm{nmol}$ (i.c.v.) & Mice & Mechanical allodynia & Orexin type-1 receptor agonist & [101] \\
\hline & S 38093 & $0.3-3 \mathrm{mg} / \mathrm{kg}$ & Rats & Cold allodynia & Histamine $\mathrm{H} 3$ receptor agonist & [102] \\
\hline & Trametinib & $0.5 \mathrm{mg} / \mathrm{kg}$ & Mice & Mechanical and cold allodynia & Inhibition of the MEK/ERK pathway & [103] \\
\hline \multirow[t]{2}{*}{ PKC/MEK/ERK } & Tamoxifen & $10-30 \mathrm{mg} / \mathrm{kg}$ & Mice & Mechanical and cold allodynia & $\begin{array}{c}\text { Inhibition of PKC/ERK/c-Fos pathway in } \\
\text { spinal cord }\end{array}$ & [104] \\
\hline & PD0325901 & $10-30 \mathrm{mg} / \mathrm{kg}$ & Mice & Mechanical and cold allodynia & Inhibition of MEK1/2 & [104] \\
\hline $\begin{array}{l}\text { Ceramide- } \\
\text { sphingosine } \\
\text { 1-phosphate }\end{array}$ & FTY720 & $0.01 \mathrm{mg} / \mathrm{kg}$ & Rats & Mechanical allodynia & Modulation of ceramide-S1P R1 & [105] \\
\hline
\end{tabular}


Table 1. Cont.

\begin{tabular}{|c|c|c|c|c|c|c|}
\hline $\begin{array}{l}\text { Therapeutic } \\
\text { Targets }\end{array}$ & Therapeutic Agents & Dose & Animals & $\begin{array}{l}\text { Symptoms that Showed } \\
\text { Improvement }\end{array}$ & Mechanisms & References \\
\hline \multirow{3}{*}{ Oxalate } & Calcium gluconate & $0.5 \mathrm{mmol} / \mathrm{kg}$ & Mice & Cold allodynia & $N / A$ & [46] \\
\hline & Calcium & $0.5 \mathrm{mmol} / \mathrm{kg}$ & Rats & Cold allodynia & $N / A$ & [13] \\
\hline & Magnesium & $0.5 \mathrm{mmol} / \mathrm{kg}$ & Rats & Cold allodynia & $N / A$ & [13] \\
\hline \multirow{4}{*}{$\begin{array}{l}\text { Thrombin } \\
\text { activity }\end{array}$} & Thrombomodulin alfa & $0.1-1 \mathrm{mg} / \mathrm{kg}$ & Rats & Mechanical allodynia & $\begin{array}{l}\text { Activation of TAFI and protein } C \text { by } \\
\text { modulating thrombin activity }\end{array}$ & [106] \\
\hline & Warfarin & $1 \mathrm{mg} / \mathrm{kg}$ & $\begin{array}{l}\text { Mice and } \\
\text { rats }\end{array}$ & Mechanical allodynia & Upregulation of HMGB1 & [107] \\
\hline & Dabigatran & $75 \mathrm{mg} / \mathrm{kg}$ & $\begin{array}{l}\text { Mice and } \\
\text { rats }\end{array}$ & Mechanical allodynia & Upregulation of HMGB1 & [107] \\
\hline & Rivaroxaban & $10 \mathrm{mg} / \mathrm{kg}$ & $\begin{array}{l}\text { Mice and } \\
\text { rats }\end{array}$ & Mechanical allodynia & Upregulation of HMGB1 & [107] \\
\hline \multirow[t]{5}{*}{ VEGF } & Bevacizumab & $1-15 \mathrm{mg} / \mathrm{kg}$ & Rats & Mechanical allodynia & Anti VEGF-A effect & [108] \\
\hline & $\begin{array}{l}17 \alpha \text {-hydroxyprogesterone } \\
\text { caproate }\end{array}$ & $10 \mathrm{mg} / \mathrm{kg}$ & Rats & Mechanical and cold allodynia & $\begin{array}{l}\text { Reduction of ATF-3, c-Fos, GFAP, Iba- } 1 \text {, } \\
\text { IL- } 1 \beta \text { and TNF } \alpha \text { in DRG and spinal cord }\end{array}$ & [109] \\
\hline & Allopregnanolone & $4 \mathrm{mg} / \mathrm{kg}$ & Rats & $\begin{array}{l}\text { Motor dysfunction and } \\
\text { electrophysiological assesment of } \\
\text { motor nerves }\end{array}$ & $N / A$ & [110] \\
\hline & Alogliptin & $10 \mathrm{mg} / \mathrm{kg}$ & Rats & $\begin{array}{c}\text { Mechanical allodynia and sciatic } \\
\text { nervedenegerations }\end{array}$ & Neuroprotective effects & [111] \\
\hline & $\begin{array}{c}\text { Aqueous Extract of Forsythia } \\
\text { viridissima }\end{array}$ & $100 \mathrm{mg} / \mathrm{kg}$ & Mice & $\begin{array}{c}\text { Mechanical allodynia and decrease } \\
\text { in IENF density }\end{array}$ & $N / A$ & [112] \\
\hline \multirow{6}{*}{ Others } & $\begin{array}{l}\text { Aqueous extract of Forsythiae } \\
\text { suspensa fruits }\end{array}$ & $50-100 \mathrm{mg} / \mathrm{kg}$ & Mice & $\begin{array}{l}\text { Mechanical allodynia and decrease } \\
\text { in IENF density }\end{array}$ & $N / A$ & [113] \\
\hline & $\begin{array}{l}\text { Aqueous extract of } \\
\text { Lithospermi Radix }\end{array}$ & $250 \mathrm{mg} / \mathrm{kg}$ & Mice & Mechanical allodynia & $\begin{array}{l}\text { Attenuation of spinal microglia } \\
\text { and astrocyte }\end{array}$ & {$[114]$} \\
\hline & Aripiprazole & $10 \mathrm{mg} / \mathrm{kg}$ & Mice & Mechanical allodynia & $N / A$ & [115] \\
\hline & Astragali radix & $100-300 \mathrm{mg} / \mathrm{kg}$ & Rats & Mechanical and thermal allodynia & $\begin{array}{l}\text { Reductions of morphometric and molecular } \\
\text { alterations in peripheral nerve and DRG, } \\
\text { and inactivation of microglia and astrocytes } \\
\text { in spinal cord and brain }\end{array}$ & [116] \\
\hline & Benztropine & $10 \mathrm{mg} / \mathrm{kg}$ & Mice & $\begin{array}{l}\text { Mecahnical, cold allodynia, and } \\
\text { demyelination in sciatic nerve }\end{array}$ & $N / A$ & [117] \\
\hline & Ceftriaxone & $200 \mathrm{mg} / \mathrm{kg}$ & Mice & Mechanical allodynia & $N / A$ & [115] \\
\hline
\end{tabular}


Table 1. Cont.

\begin{tabular}{|c|c|c|c|c|c|c|}
\hline $\begin{array}{l}\text { Therapeutic } \\
\text { Targets }\end{array}$ & Therapeutic Agents & Dose & Animals & $\begin{array}{l}\text { Symptoms that Showed } \\
\text { Improvement }\end{array}$ & Mechanisms & References \\
\hline & Cinnamomi Cortex & $100-400 \mathrm{mg} / \mathrm{kg}$ & Rats & Cold allodynia & $\begin{array}{c}\text { Attenuation of spinal microglia and } \\
\text { astrocyte, and downregulation of IL-1 } \beta \\
\text { and TNF- } \alpha\end{array}$ & [118] \\
\hline & Cryptotanshinone & $10-30 \mathrm{mg} / \mathrm{kg}$ & Mice & Cold allodynia & $N / A$ & [119] \\
\hline & Curcumin & $10 \mathrm{mg} / \mathrm{kg}$ & Rats & Neurodegeneration in sciatic nerve & $\begin{array}{l}\text { Downregulation of neurotensin and } \\
\text { platinum concentrations in sciatic nerve }\end{array}$ & {$[120]$} \\
\hline & Elcatonin & $20 \mathrm{U} / \mathrm{kg}$ & Rats & Mechanical and cold allodynia & $N / A$ & [54] \\
\hline & Fulvestrant & $5-10 \mathrm{mg} / \mathrm{kg}$ & Rats & $\begin{array}{c}\text { Mechanical allodynia and sciatic } \\
\text { nervedenegerations }\end{array}$ & Neuroprotective effects & [122] \\
\hline & Goshajinkigan & $300-1000 \mathrm{mg} / \mathrm{kg}$ & Mice & Mechanical and cold allodynia & $N / A$ & [123] \\
\hline & Goshajinkigan & $300-1000 \mathrm{mg} / \mathrm{kg}$ & Rats & Mechanical and cold allodynia & $N / A$ & [124] \\
\hline & Hirudin & $10 \mathrm{mg} / \mathrm{kg}$ & Mice & Mechanical allodynia & $\begin{array}{c}\text { Downregulation of } \mathrm{p} 38, \mathrm{HIF}-1 \alpha \text { and } \\
\text { MMP-9/2 }\end{array}$ & [125] \\
\hline \multirow[t]{6}{*}{ Others } & HM01 & $10-30 \mathrm{mg} / \mathrm{kg}$ & Rats & $\begin{array}{l}\text { Nerveconductionvelocity of digital } \\
\text { nerve, caudal nerve and } \\
\text { IENF density }\end{array}$ & Ghrelin agonist & [126] \\
\hline & Melatonin & $3-10 \mathrm{mg} / \mathrm{kg}$ & Mice & Mechanical and cold allodynia & $\begin{array}{l}\text { Antioxidant effect, improvement of } \\
\text { mitochondrial function, activation of } \\
\text { autophagy pathway, and } \\
\text { anti-apoptotic effect }\end{array}$ & [127] \\
\hline & Metformin & $250 \mathrm{mg} / \mathrm{kg}$ & Rats & $\begin{array}{c}\text { Mecahnical, cold allodynia, } \\
\text { decrease in IENF density, and } \\
\text { increase in GFAP of spinal cord }\end{array}$ & $N / A$ & [128] \\
\hline & Metformin & $250 \mathrm{mg} / \mathrm{kg}$ & Mice & Mechanical allodynia & $\begin{array}{c}\text { Decreases in ATF-3 and c-Fos expressions } \\
\text { in spinal cord and DRG }\end{array}$ & [129] \\
\hline & $\begin{array}{l}\text { Neurotropin (a non-protein } \\
\text { extract derived from the inflamed } \\
\text { skin of rabbits inoculated with } \\
\text { vaccinia virus) }\end{array}$ & $100-200 \mathrm{U} / \mathrm{kg}$ & Rats & Mechanical and cold allodynia & $\begin{array}{l}\text { Monoaminergic descending pain inhibitory } \\
\text { system via Gi protein-coupled receptors }\end{array}$ & [130] \\
\hline & $\begin{array}{l}\text { Neurotropin (a non-protein } \\
\text { extract derived from the inflamed } \\
\text { skin of rabbits inoculated with } \\
\text { vaccinia virus) }\end{array}$ & $200 \mathrm{U} / \mathrm{kg}$ & Rats & Mechanical allodynia & Neuroprotective effects & [131] \\
\hline
\end{tabular}


Table 1. Cont.

\begin{tabular}{|c|c|c|c|c|c|c|}
\hline $\begin{array}{c}\text { Therapeutic } \\
\text { Targets }\end{array}$ & Therapeutic Agents & Dose & Animals & $\begin{array}{l}\text { Symptoms that Showed } \\
\text { Improvement }\end{array}$ & Mechanisms & References \\
\hline \multirow{10}{*}{ Others } & Ninjin'yoeito & $1000 \mathrm{mg} / \mathrm{kg}$ & Mice & Mechanical and cold allodynia & $N / A$ & [132] \\
\hline & Palmitoylethanolamine & $30 \mathrm{mg} / \mathrm{kg}$ & Rats & Mechanical and cold allodynia & $\begin{array}{l}\text { Neuroprotective effects and } \\
\text { glia-activation prevention }\end{array}$ & [133] \\
\hline & Phenytoin & $5-10 \mathrm{mg} / \mathrm{kg}$ & Mice & Cold allodynia & $N / A$ & [48] \\
\hline & Processed aconite root & $1000 \mathrm{mg} / \mathrm{kg}$ & Mice & Mechanical and cold allodynia & $N / A$ & [134] \\
\hline & Retigabine & $5-10 \mathrm{mg} / \mathrm{kg}$ & Mice & Cold allodynia & $N / A$ & {$[48]$} \\
\hline & Salmon calcitonin & $20 \mathrm{U} / \mathrm{kg}$ & Rats & Mechanical and cold allodynia & $N / A$ & [135] \\
\hline & Tanshinone IIA & $25 \mathrm{mg} / \mathrm{kg}$ & Rats & $\begin{array}{l}\text { Mecahnical, cold allodynia, and } \\
\text { demyelination in sciatic nerve }\end{array}$ & $\begin{array}{l}\text { Mitochondrial protection and } \\
\text { autophagy promotion }\end{array}$ & [136] \\
\hline & Tanshinone IIA & $10 \mathrm{mg} / \mathrm{kg}$ & Mice & Cold allodynia & $N / A$ & [119] \\
\hline & Topiramate & $100 \mathrm{mg} / \mathrm{kg}$ & Rats & $\begin{array}{c}\text { Mechanical allodynia, dischange in } \\
\text { nerve sensory conduction velocity, } \\
\text { caudal nerve fibers density, and } \\
\text { IENF density }\end{array}$ & $N / A$ & [137] \\
\hline & $\begin{array}{l}\text { Water extract of Lepidium } \\
\text { meyenii root }\end{array}$ & $10,000 \mathrm{mg} / \mathrm{kg}$ & Rats & Mechanical allodynia & $N / A$ & [138] \\
\hline
\end{tabular}

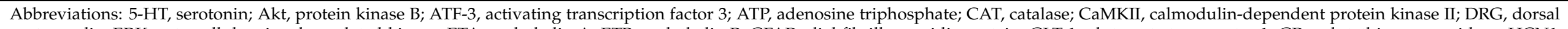

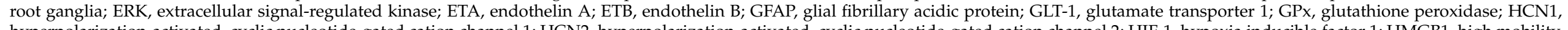

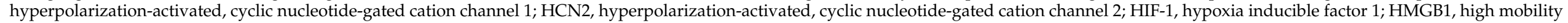

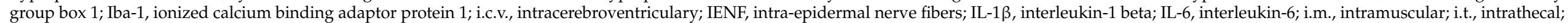

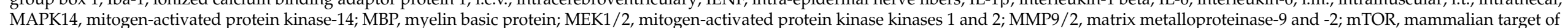

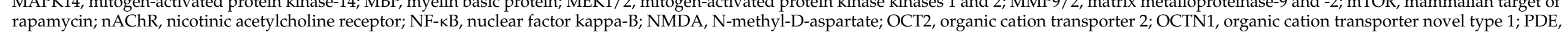

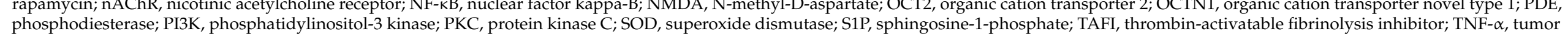

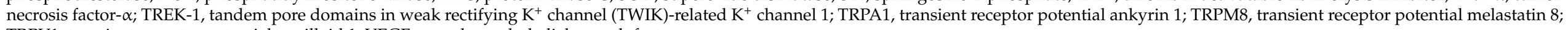
TRPV1, transient receptor potential vanilloid 1; VEGF, vascular endothelial growth factor. 


\subsection{Antioxidants}

Many previous preclinical reports support that oxidative stress plays a role in oxaliplatinrelated peripheral neuropathy $[27,140,141]$. Vitamin C, vitamin E, acetyl L-carnitine, alphalipoic acid, and glutathione, which are widely known for their antioxidant effects, have been reported to alleviate the peripheral neuropathy of oxaliplatin in rodents [14-16,23,34]. Among the approved drugs, carvedilol, donepezil, dimethyl fumarate, and rosiglitazone have also been reported to reverse the neurotoxicity of oxaliplatin via their antioxidant effects [18,21,22,32]. Moreover, many agents, which have antioxidant effects, inhibit oxaliplatincaused peripheral neuropathy in preclinical studies $[17,19,20,24-26,28-31,33,35-38]$.

\subsection{Anti-Inflammatory Agents}

Inflammatory cytokines such as IL-1 $\beta$, IL-6, and TNF- $\alpha$ were elevated in the dorsal root ganglion (DRG) and spinal cord of oxaliplatin-treated animals, and some agents reduced the peripheral neuropathy symptoms via their anti-inflammatory effects [39,41,42]. Activations of astrocytes and microglia were also observed in the spinal dorsal horn after oxaliplatin administrations, and minocycline, rapamycin, and fluorocitrate inhibited these spinal changes and prevented neurological damage [40,43,44].

\subsection{Sodium Channel Inhibitors}

Oxaliplatin-induced acute neuropathy is termed a 'channelopathy', as oxaliplatin and oxalate modulated voltage-gated $\mathrm{Na}^{+}$and $\mathrm{K}^{+}$channels in several types of neurons $[3,142,143]$. For example, oxaliplatin increases the amplitude and duration of compound action potentials interacting with voltage-gated $\mathrm{Na}^{+}$channels in rat sensory neurons [142]. Furthermore, oxaliplatin prolongs the duration of the A-fiber compound action potential related to $\mathrm{K}^{+}$ channels [3]. Thus, the effect of oxaliplatin on $\mathrm{Na}^{+}$and $\mathrm{K}^{+}$channels is thought to be involved in acute neuropathy [4]. Many $\mathrm{Na}^{+}$channel inhibitors, such as lidocaine, mexiletine, and lamotrigine have been reported to ameliorate the neuropathic symptoms of oxaliplatin, especially the acute neuropathy [11,45-49].

\subsection{Potassium Channel Modulators}

Glucosinolate glucoraphanin, isothiocyanate sulforaphane, allyl-isothiocyanate, phenylisothiocyanate and carboxyphenyl-isothiocyanate inhibited oxaliplatin-induced neuropathy by modulating Kv7 channels [50,51]. It has been reported that tandem pore domains in weak rectifying $\mathrm{K}^{+}$channel (TWIK)-related $\mathrm{K}^{+}$channel 1 (TREK-1) channels are partially involved in the inhibitory effect of riluzole on oxaliplatin-induced peripheral neuropathy [52].

\subsection{Calcium Channel $\alpha 2 \delta$ Ligands}

In animal studies only, gabapentin and pregabalin, which act on $\alpha 2 \delta$, reduced the symptoms of oxaliplatin neuropathy $[11,46,48,53,54]$.

\subsection{Transient Receptor Potential (TRP) Modulators}

It has been reported that temperature-sensitive cation channels, such as transient receptor potential ankyrin 1 (TRPA1), transient receptor potential melastatin 8 (TRPM8), and transient receptor potential vanilloid 1 (TRPV1), are involved in oxaliplatin-induced peripheral neuropathy [144-146]. It has also been reported that the amelioration of oxaliplatin neuropathy by topiramate, acetazolamide, shakuyakukanzoto, goshajinkigan, eel calcitonin, nifedipine, diltiazem, and mexiletine, is partly due to the downregulation or modulation of TRP channels [55-60].

\subsection{Modulators of Glutamate Nervous System}

Some studies indicated that the excessive spinal transmission activities, such as spinal glutamate uptake and spinal N-methyl-D-aspartate receptor subtype NR2B subunit overexpression, are involved in painful neuropathic symptoms related to oxaliplatin [64,69,71]. Riluzole, mirtazapine, ifenprodil, amitriptyline, trifluoperazine, dimiracetam, E2072, and 
Tat-HA-NR2B9c targeted these glutamatergic nervous systems and showed that oxaliplatin reduced neurotoxicity [64-71].

\subsection{Modulators of Monoamine Nervous System}

Monoamines, including noradrenalin and serotonin, play an important role in the descending pain inhibitory system [147]. In also the oxaliplatin peripheral neuropathy animal models, many drugs, such as, duloxetine, fluoxetine, vortioxetine, tandospirone, venlafaxine, xaliproden, clomipramine, and clonidine, also showed analgesic effects by modulating the monoamine nervous system [11,80-94].

\subsection{Others}

In addition to the above, many other drugs have been identified to reduce oxaliplatininduced peripheral neuropathy via several therapeutic targets, such as acetylcholine receptors [95-98], thrombin [106,107], protein kinase C/mitogen-activated protein kinase and extracellular signal-regulated kinase signal $[103,104]$, organic cation transporter $[99,100]$, opioid receptors [46,78-80], phosphodiesterase [72,73], hyperpolarization-activated, cyclic nucleotide-gated cation channel [61,62], imidazoline receptors [63], endothelin receptor [74], cannabinoid receptors [75], sigma-1 receptors [76,77], orexin receptors [101], histamine receptors [102], ceramide-sphingosine 1-phosphate [105], chelate of oxalate [11,13], vascular endothelial growth factor [108], and others [48,54,109-139], at the basic research.

\section{Therapeutic Agents in Clinical Evidence}

We analyzed the articles found in PubMed with the search term "oxaliplatin neuropathy or oxaliplatin neurotoxicity" limited to "clinical trials". The last search date was 25 June 2020. Reports other than randomized trials and meta-analyses were excluded. Moreover, Information such as the investigational drug and its dosage, chemotherapy received by the patient, study design, number of patients, and results was collected.

There were 533 articles in PubMed for the search term "oxaliplatin neuropathy or oxaliplatin neurotoxicity" limited to "clinical trials". Of these, 127 articles reported on drugs that inhibit oxaliplatin-induced peripheral neuropathy in animal studies. After excluding reports other than randomized trials and meta-analyses, the authors found 16 reports that they considered to be clinically important. A summarized list of the representative randomized controlled trials and meta-analyses on prophylactic and therapeutic agents for oxaliplatin-induced peripheral neuropathy is shown below in Table 2. 
Table 2. The therapeutic drugs for oxaliplati-induced peripheral neuropathy in clinical experiments.

\begin{tabular}{|c|c|c|c|c|c|c|}
\hline $\begin{array}{l}\text { Investigational } \\
\text { Drug }\end{array}$ & Dose & Chemotherapy & Study Design & $\begin{array}{l}\text { Patient } \\
\text { Number }\end{array}$ & Summary & References \\
\hline Duloxetine & $\begin{array}{l}60 \mathrm{mg} / \text { day } \\
(30 \mathrm{mg} / \text { day for the first week })\end{array}$ & Taxane or platinum & $\begin{array}{l}\text { Randomized, } \\
\text { double-blind, } \\
\text { placebo-controlled, } \\
\text { cross-over }\end{array}$ & 231 & $\begin{array}{l}\text { RRs }(95 \% \text { CI) of experiencing } 30 \% \text { and } 50 \% \text { pain reduction } \\
\text { were } 1.96(1.15-3.35) \text { and } 2.43(1.11-5.30) \text {, respectively. }\end{array}$ & [148] \\
\hline \multirow{3}{*}{$\begin{array}{l}\text { Calcium and } \\
\text { magnesium }\end{array}$} & $\begin{array}{l}\text { Calcium gluconate, } 1 \mathrm{~g} ; \\
\text { magnesium sulfate, } 1 \mathrm{~g} \text { (pre- and } \\
\text { post-oxaliplatin) }\end{array}$ & Oxaliplatin & $\begin{array}{l}\text { Randomized, } \\
\text { double-blind, } \\
\text { placebo-controlled }\end{array}$ & 102 & $\begin{array}{c}\text { Significant improvements in incidence of } \geq \text { Grade } 2 \\
\text { neuropathy, oxaliplatin-specific scale, and acute } \\
\text { muscle spasms }\end{array}$ & [149] \\
\hline & $\begin{array}{l}\text { Calcium gluconate, } 1 \mathrm{~g} ; \\
\text { magnesium sulfate, } 1 \mathrm{~g} \text { (pre- and } \\
\text { post-oxaliplatin, or } \\
\text { pre-oxaliplatin) }\end{array}$ & Oxaliplatin & $\begin{array}{l}\text { Randomized, } \\
\text { double-blind, } \\
\text { placebo-controlled }\end{array}$ & 353 & No significant differences compared to placebo group & [151] \\
\hline & $\begin{array}{l}\text { Calcium gluconate, } 1 \mathrm{~g} ; \\
\text { magnesium sulfate, } 1 \mathrm{~g} \text { (pre- and } \\
\text { post-oxaliplatin) }\end{array}$ & Oxaliplatin & $\begin{array}{l}\text { Randomized, } \\
\text { double-blind, } \\
\text { placebo-controlled, } \\
\text { cross-over }\end{array}$ & 19 & No significant differences compared to placebo group & [152] \\
\hline \multirow{4}{*}{ Goshajinkigan } & $N / A$ & Oxaliplatin & Meta-analysis & 694 & $\begin{array}{l}\text { No significant differences compared to control group } \\
\text { RRs ( } 95 \% \text { CI) of the incidence of } \geq \text { Grade } 2 \text { neuropathy } \\
\text { and } \geq \text { Grade } 1 \text { chronic neuropathy were } 0.81 \text { (0.60-1.11) } \\
\text { and } 0.95 \text { (0.69-1.32), respectively. }\end{array}$ & [153] \\
\hline & $7.5 \mathrm{~g} /$ day & Oxaliplatin & $\begin{array}{l}\text { Randomized, } \\
\text { controlled }\end{array}$ & 45 & $\begin{array}{l}\text { Significant improvement in incidence of } \geq \text { Grade } 2 \\
\text { neuropathy compared control group }\end{array}$ & [154] \\
\hline & $7.5 \mathrm{~g} /$ day & Oxaliplatin & $\begin{array}{l}\text { Randomized, } \\
\text { double-blind, } \\
\text { placebo-controlled }\end{array}$ & 93 & No significant differences compared to placebo group & [155] \\
\hline & $7.5 \mathrm{~g} /$ day & Oxaliplatin & $\begin{array}{l}\text { Randomized, } \\
\text { double-blind, } \\
\text { placebo-controlled }\end{array}$ & 188 & $\begin{array}{l}\text { Significant increase in incidence of } \geq \text { Grade } 2 \text { neuropathy } \\
\text { compared placebo group }\end{array}$ & [156] \\
\hline $\begin{array}{l}\text { Alpha-lipoic } \\
\text { acid }\end{array}$ & $1800 \mathrm{mg} /$ day & $\begin{array}{l}\text { Cisplatin or } \\
\text { oxaliplatin }\end{array}$ & $\begin{array}{l}\text { Randomized, } \\
\text { double-blind, } \\
\text { placebo-controlled }\end{array}$ & 243 & $\begin{array}{l}\text { No significant differences compared to placebo group for } \\
\text { FACT/GOG-Ntx scores, BPI scores, and patients' } \\
\text { functional outcomes. }\end{array}$ & [157] \\
\hline
\end{tabular}


Table 2. Cont.

\begin{tabular}{|c|c|c|c|c|c|c|}
\hline $\begin{array}{l}\text { Investigational } \\
\text { Drug }\end{array}$ & Dose & Chemotherapy & Study Design & $\begin{array}{l}\text { Patient } \\
\text { Number }\end{array}$ & Summary & References \\
\hline Vitamin E & $400 \mathrm{mg} /$ day & Oxaliplatin & $\begin{array}{l}\text { Randomized, } \\
\text { controlled }\end{array}$ & 65 & No significant differences compared to control group & [158] \\
\hline Glutathione & $1500 \mathrm{mg} / \mathrm{m}^{2}$ & Oxaliplatin & $\begin{array}{l}\text { Randomized, } \\
\text { double-blind, } \\
\text { placebo-controlled }\end{array}$ & 52 & $\begin{array}{c}\text { Significant improvements in incidence of } \geq \text { Grade } \\
2 \text { neuropathy and neurophysiological findings compared } \\
\text { placebo group }\end{array}$ & [160] \\
\hline Calmangafodipir & $2-10 \mu \mathrm{mol} / \mathrm{kg}$ & Oxaliplatin & $\begin{array}{l}\text { Randomized, } \\
\text { controlled }\end{array}$ & 173 & $\begin{array}{c}\text { Significant improvements in Leonard scale compared to } \\
\text { control group }\end{array}$ & [161] \\
\hline Pregabalin & $150-600 \mathrm{mg} / \mathrm{kg}$ & Oxaliplatin & $\begin{array}{l}\text { Randomized, } \\
\text { double-blind, } \\
\text { placebo-controlled }\end{array}$ & 199 & $\begin{array}{l}\text { No significant differences compared to placebo group in } \\
\text { pain score }\end{array}$ & [162] \\
\hline Minocycline & $200 \mathrm{mg} /$ day & Oxaliplatin & Randomized & 66 & No significant differences compared to control group & [163] \\
\hline
\end{tabular}


Duloxetine was tested in a randomized, double-blind, placebo-controlled, cross-over trial, for its ability to treat neuropathy in patients with taxane or platinum [148]. In this study, relative risks (RRs) (95\% confidence interval (CI)) of experiencing 30\% and 50\% pain reduction were 1.96 (1.15-3.35) and 2.43 (1.11-5.30), respectively. A sub-analysis of this study indicates that duloxetine is more effective than taxanes in treating platinuminduced neuropathy.

Intravenous injection of calcium and magnesium is thought to chelate oxalate, and the preventive effects for oxaliplatin-induced peripheral neurotoxicity have been investigated since before [149-152]. Some studies reported significant inhibitory effects on oxaliplatinrelated neuropathy $[149,150]$, some studies did not confirm significant effects [151,152]. The results of a meta-analysis including five studies showed that calcium and magnesium had no significant effect on neuropathy (relative risks (RRs) (95\% CI) of incidence of $\geq$ Grade 2 neuropathy and $\geq$ Grade 1 chronic neuropathy were $0.81(0.60-1.11)$ and 0.95 (0.69-1.32), respectively.) [153].

Goshajinkigan, a Japanese herbal medicine, has been studied in several clinical trials [154-156]. In a randomized controlled trial, goshajinkigan significantly reduced the incidence of Grade 2 or higher neuropathy [154]. In goshajinkigan oxaliplatin neurotoxicity evaluation (GONE) study, the incidence of Grade 2 or higher neuropathy until the 8th cycle was 39 and 51\% in goshajinkigan and placebo groups, respectively, which was not statistically significant [155]. This study concluded that goshajinkigan appears to have an acceptable safety margin and a promising effect in delaying the onset of Grade 2 or greater peripheral neuropathy [155]. However, in the interim analysis of goshajinkigan effect for oxaliplatin neurotoxicity inhibition using mFOLFOX6 regimen (GENIUS) study, a multicenter randomized, double-blind, placebo-controlled trial, goshajinkigan significantly increased the incidence of neuropathy [156].

Alpha-lipoic acid and vitamin E, both of which have antioxidant properties, were also examined in clinical trials for their effects on neuropathy in patients using oxaliplatin [157-159]. However, neither has been reported to significantly improve neuropathy. Beside, glutathione and calmangafordipir, which also have antioxidant effects, were found to significantly improve neuropathy related oxaliplatin treatment in randomized trials $[160,161]$. However, the dose of glutathione used in this clinical trial was high $\left(1.5 \mathrm{~g} / \mathrm{m}^{2}\right)$, and calmangafodipir is undergoing Phase III trials and not approved as a drug at this time. Other drugs such as pregabalin, a general-purpose drug for neuropathic pain, and minocycline, a glial attenuator, have also been tested in clinical trials, but no significant inhibitory effects have been reported [162,163].

As described above, few drugs have shown clear therapeutic effects on oxaliplatininduced peripheral neuropathy in clinical trials. Thus, according to the clinical practice guideline updated by the American Society of Clinical Oncology in 2020, no agents have yet to be recommended for preventing chemotherapy-induced peripheral neuropathy and only duloxetine may be used as a treatment for neuropathy [10].

\section{Discussion}

Recently, the mechanism of oxaliplatin-induced peripheral neuropathy has been elucidated in basic studies, and many drugs and agents targeting this mechanism have been explored and identified for therapy for oxaliplatin-induced peripheral neuropathy. In particular, many inhibitors of neuropathy targeting oxidative stress, inflammatory response, sodium channel, TRP channel, glutamate nervous system, and monoamine nervous system have been identified as candidates for inhibiting oxaliplatin-induced neuropathy in animal research.

Alternatively, very few drugs have shown the efficacy of oxaliplatin for peripheral neuropathy in clinical trials. The American Society of Clinical Oncology's clinical practice guideline states that only duloxetine can be used for the treatment of chemotherapyinduced peripheral neuropathy [10]. Since duloxetine has been shown to improve pain in clinical trials [148], its use in patients with pain may be beneficial. However, consideration 
should be given to side effects such as drowsiness, headache, and dizziness. Goshajinkigan and glutathione are drugs that have few side effects, thus they can be considered easy to treat in patients. Goshajinkigan has been reported both to have therapeutic effects on oxaliplatin-induced peripheral neuropathy and not to have the effects [154-156]. In an animal study, it has been reported that goshajinkigan does not inhibit the progression of chronic neuropathy, but rather relieves neuropathic symptoms [124]. Therefore, it may be used to relieve symptoms in patients with oxaliplatin-induce neuropathy.

While many drugs have been reported in basic research as having the potential to inhibit the neuropathy by oxaliplatin, few drugs have developed sufficient evidence in clinical studies. The "valley of death" between basic researches and clinical applications is considered caused by many issues, including the difference between clinical symptoms and animal assessment methods, the cost and time of conducting clinical research, safety considerations in clinical application, and the lack of collaboration between basic and clinical researchers. It is important to promote translational research, that is, to bridge basic research to clinical research.

Funding: This research received no external funding

Acknowledgments: This work was partly supported by Japan Society for the Promotion of Science (JSPS) KAKENHI (JP20K07198).

Conflicts of Interest: The authors declare that they have no conflicts of interest to this work.

$\begin{array}{ll}\text { Abbreviations } & \\ \text { 5-HT } & \text { Serotonin } \\ \text { 95\% CI } & \text { 95\% confidence interval } \\ \text { Akt } & \text { protein kinase B } \\ \text { ATF-3 } & \text { activating transcription factor 3 } \\ \text { ATP } & \text { adenosine triphosphate } \\ \text { CAT } & \text { Catalase } \\ \text { CaMKII } & \text { calmodulin-dependent protein kinase II } \\ \text { DRG } & \text { dorsal root ganglia } \\ \text { ERK } & \text { extracellular signal-regulated kinase } \\ \text { ETA } & \text { endothelin A } \\ \text { ETB } & \text { endothelin B } \\ \text { FACT/GOG-NTx } & \text { Functional Assessment of Cancer Therapy /Gynecologic } \\ \text { GENIUS } & \text { Group-Neurotoxicity } \\ \text { goshajinkigan effect for oxaliplatin neurotoxicity inhibition using } \\ \text { GFAP } & \text { mFOLFOX6 regimen } \\ \text { GLT-1 } & \text { glial fibrillary acidic protein } \\ \text { GONE } & \text { glutamate transporter 1 } \\ \text { GPx } & \text { goshajinkigan oxaliplatin neurotoxicity evaluation } \\ \text { HCN1 } & \text { glutathione peroxidase } \\ \text { HCN2 } & \text { hyperpolarization-activated, cyclic nucleotide-gated cation channel 1 } \\ \text { HIF-1 } & \text { hyperpolarization-activated, cyclic nucleotide-gated cation channel 2 } \\ \text { HMGB1 } & \text { hypoxia inducible factor 1 } \\ \text { Iba-1 } & \text { high mobility group box 1 } \\ \text { i.c.v. } & \text { ionized calcium binding adaptor protein 1 } \\ \text { IENF } & \text { intracerebroventriculary } \\ \text { IL-1 } \beta & \text { intra-epidermal nerve fibers } \\ \text { IL-6 } & \text { interleukin-1 beta } \\ \text { i.m. } & \text { interleukin-6 } \\ \text { i.t. } & \text { intramuscular } \\ \text { JSPS } & \text { Japan Society for the Promotion of Science } \\ \text { MAPK14 } & \text { mBP }\end{array}$




$\begin{array}{ll}\text { MEK1/2 } & \text { mitogen-activated protein kinase kinases } 1 \text { and } 2 \\ \text { MMP9/2 } & \text { matrix metalloproteinase-9 and -2 } \\ \text { mTOR } & \text { mammalian target of rapamycin } \\ \text { nAChR } & \text { nicotinic acetylcholine receptor } \\ \text { NF-KB } & \text { nuclear factor kappa-B } \\ \text { NMDA } & \text { N-methyl-D-aspartate } \\ \text { OCT2 } & \text { organic cation transporter } 2 \\ \text { OCTN1 } & \text { organic cation transporter novel type 1 } \\ \text { PDE } & \text { phosphodiesterase } \\ \text { PI3K } & \text { phosphatidylinositol-3 kinase } \\ \text { PKC } & \text { protein kinase C } \\ \text { RR } & \text { relative risk } \\ \text { SOD } & \text { superoxide dismutase } \\ \text { S1P } & \text { sphingosine-1-phosphate } \\ \text { TAFI } & \text { thrombin-activatable fibrinolysis inhibitor } \\ \text { TNF- } \alpha & \text { tumor necrosis factor- } \alpha \\ \text { TREK-1 } & \text { tandem pore domains in weak rectifying } \mathrm{K}^{+} \text {channel (TWIK)-related } \mathrm{K}^{+} \text {channel } 1 \\ \text { TRPA1 } & \text { transient receptor potential ankyrin } 1 \\ \text { TRPM8 } & \text { transient receptor potential melastatin } 8 \\ \text { TRPV1 } & \text { transient receptor potential vanilloid 1 } \\ \text { VEGF } & \text { vascular endothelial growth factor }\end{array}$

\section{References}

1. Wilson, R.H.; Lehky, T.; Thomas, R.R.; Quinn, M.G.; Floeter, M.K.; Grem, J.L. Acute oxaliplatin-induced peripheral nerve hyperexcitability. J. Clin. Oncol. 2002, 20, 1767-1774. [CrossRef]

2. Argyriou, A.A.; Bruna, J.; Marmiroli, P.; Cavaletti, G. Chemotherapy-induced peripheral neurotoxicity (CIPN): An update. Crit. Rev. Oncol. Hematol. 2012, 82, 51-77. [CrossRef]

3. Pasetto, L.M.; D'Andrea, M.R.; Rossi, E.; Monfardini, S. Oxaliplatin-related neurotoxicity: How and why? Crit. Rev Oncol. Hematol. 2006, 59, 159-168. [CrossRef]

4. Sittl, R.; Lampert, A.; Huth, T.; Schuy, E.T.; Link, A.S.; Fleckenstein, J.; Alzheimer, C.; Grafe, P.; Carr, R.W. Anticancer drug oxaliplatin induces acute cooling-aggravated neuropathy via sodium channel subtype $\mathrm{Na}(\mathrm{V}) 1.6$-resurgent and persistent current. Proc. Natl. Acad. Sci. USA 2012, 24, 6704-6709. [CrossRef] [PubMed]

5. Kagiava, A.; Tsingotjidou, A.; Emmanouilides, C.; Theophilidis, G. The effects of oxaliplatin, an anticancer drug, on potassium channels of the peripheral myelinated nerve fibres of the adult rat. Neurotoxicology 2008, 29, 1100-1106. [CrossRef] [PubMed]

6. Nakagawa, T.; Kaneko, S. Roles of Transient Receptor Potential Ankyrin 1 in Oxaliplatin-Induced Peripheral Neuropathy. Biol. Pharm. Bull. 2017, 40, 947-953. [CrossRef] [PubMed]

7. Lehky, T.J.; Leonard, G.D.; Wilson, R.H.; Grem, J.L.; Floeter, M.K. Oxaliplatin-induced neurotoxicity: Acute hyperexcitability and chronic neuropathy. Muscle Nerve. 2004, 29, 387-392. [CrossRef] [PubMed]

8. Jamieson, S.M.; Liu, J.; Connor, B.; McKeage, M.J. Oxaliplatin causes selective atrophy of a subpopulation of dorsal root ganglion neurons without inducing cell loss. Cancer Chemother. Pharmacol. 2005, 56, 391-399. [CrossRef]

9. Tsutsumi, K.; Yamashita, Y.; Ushio, S.; Kawashiri, T.; Kaname, T.; Fujita, S.; Oishi, R.; Egashira, N. Oxaliplatin induces hypomyelination and reduced neuregulin 1 expression in the rat sciatic nerve. Neurosci. Res. 2014, 80, 86-90. [CrossRef] [PubMed]

10. Loprinzi, C.L.; Lacchetti, C.; Bleeker, J.; Cavaletti, G.; Chauhan, C.; Hertz, D.L.; Kelley, M.R.; Lavino, A.; Lustberg, M.B.; Paice, J.A.; et al. Prevention and Management of Chemotherapy-Induced Peripheral Neuropathy in Survivors of Adult Cancers: ASCO Guideline Update. J. Clin. Oncol. 2020, 38, 3325-3348. [CrossRef]

11. Ling, B.; Authier, N.; Balayssac, D.; Eschalier, A.; Coudore, F. Behavioral and pharmacological description of oxaliplatin-induced painful neuropathy in rat. Pain 2007, 128, 225-234. [CrossRef] [PubMed]

12. Ta, L.E.; Low, P.A.; Windebank, A.J. Mice with cisplatin and oxaliplatin-induced painful neuropathy develop distinct early responses to thermal stimuli. Mol. Pain 2009, 26, 9. [CrossRef] [PubMed]

13. Sakurai, M.; Egashira, N.; Kawashiri, T.; Yano, T.; Ikesue, H.; Oishi, R. Oxaliplatin-induced neuropathy in the rat: Involvement of oxalate in cold hyperalgesia but not mechanical allodynia. Pain 2009, 15, 165-174. [CrossRef] [PubMed]

14. Ghirardi, O.; Lo Giudice, P.; Pisano, C.; Vertechy, M.; Bellucci, A.; Vesci, L.; Cundari, S.; Miloso, M.; Rigamonti, L.M.; Nicolini, G.; et al. Acetyl-L-Carnitine prevents and reverts experimental chronic neurotoxicity induced by oxaliplatin, without altering its antitumor properties. Anticancer. Res. 2005, 25, 2681-2687. [PubMed]

15. Joseph, E.K.; Chen, X.; Bogen, O.; Levine, J.D. Oxaliplatin acts on IB4-positive nociceptors to induce an oxidative stress-dependent acute painful peripheral neuropathy. J. Pain. 2008, 9, 463-472. [CrossRef]

16. Zheng, H.; Xiao, W.H.; Bennett, G.J. Functional deficits in peripheral nerve mitochondria in rats with paclitaxel- and oxaliplatinevoked painful peripheral neuropathy. Exp. Neurol. 2011, 232, 154-161. [CrossRef] 
17. Canta, A.; Chiorazzi, A.; Pozzi, E.; Fumagalli, G.; Monza, L.; Meregalli, C.; Cavaletti, G. Calmangafodipir reduces sensory alterations and prevents intraepidermal nerve fibers loss in a mouse model of oxaliplatin induced peripheral neurotoxicity. Antioxidants 2020, 9, 594. [CrossRef]

18. Areti, A.; Komirishetty, P.; Kumar, A. Carvedilol prevents functional deficits in peripheral nerve mitochondria of rats with oxaliplatin-evoked painful peripheral neuropathy. Toxicol. Appl. Pharmacol. 2017, 322, 97-103. [CrossRef]

19. Abdelhamid, A.M.; Mahmoud, S.S.; Abdelrahman, A.E.; Said, N.M.; Toam, M.; Samy, W.; Amer, M.A. Protective effect of cerium oxide nanoparticles on cisplatin and oxaliplatin primary toxicities in male albino rats. Naunyn Schmiedebergs Arch. Pharmacol. 2020, 393, 2411-2425. [CrossRef]

20. Kawashiri, T.; Kobayashi, D.; Egashira, N.; Tsuchiya, T.; Shimazoe, T. Oral administration of Cystine and Theanine ameliorates oxaliplatin-induced chronic peripheral neuropathy in rodents. Sci. Rep. 2020, 10, 12665. [CrossRef]

21. Miyagi, A.; Kawashiri, T.; Shimizu, S.; Shigematsu, N.; Kobayashi, D.; Shimazoe, T. Dimethyl Fumarate Attenuates OxaliplatinInduced Peripheral Neuropathy without Affecting the Anti-tumor Activity of Oxaliplatin in Rodents. Biol. Pharm Bull. 2019, 42, 638-644. [CrossRef] [PubMed]

22. Kawashiri, T.; Shimizu, S.; Shigematsu, N.; Kobayashi, D.; Shimazoe, T. Donepezil ameliorates oxaliplatin-induced peripheral neuropathy via a neuroprotective effect. J. Pharmacol. Sci. 2019, 140, 291-294. [CrossRef] [PubMed]

23. Lee, M.; Cho, S.; Roh, K.; Chae, J.; Park, J.H.; Park, J.; Lee, M.A.; Kim, J.; Auh, C.K.; Yeom, C.H.; et al. Glutathione alleviated peripheral neuropathy in oxaliplatin-treated mice by removing aluminum from dorsal root ganglia. Am. J. Transl. Res. 2017, 15, 926-939.

24. Celik, H.; Kucukler, S.; Ozdemir, S.; Comakli, S.; Gur, C.; Kandemir, F.M.; Yardim, A. Lycopene protects against central and peripheral neuropathy by inhibiting oxaliplatin-induced ATF-6 pathway, apoptosis, inflammation and oxidative stress in brains and sciatic tissues of rats. Neurotoxicology 2020, 80, 29-40. [CrossRef]

25. Waseem, M.; Tabassum, H.; Parvez, S. Neuroprotective effects of melatonin as evidenced by abrogation of oxaliplatin induced behavioral alterations, mitochondrial dysfunction and neurotoxicity in rat brain. Mitochondrion 2016, 30, 168-176. [CrossRef]

26. Janes, K.; Doyle, T.; Bryant, L.; Esposito, E.; Cuzzocrea, S.; Ryerse, J.; Bennett, G.J.; Salvemini, D. Bioenergetic deficits in peripheral nerve sensory axons during chemotherapy-induced neuropathic pain resulting from peroxynitrite-mediated post-translational nitration of mitochondrial superoxide dismutase. Pain 2013, 154, 2432-2440. [CrossRef]

27. Di Cesare Mannelli, L.; Zanardelli, M.; Landini, I.; Pacini, A.; Ghelardini, C.; Mini, E.; Bencini, A.; Valtancoli, B.; Failli, P. Effect of the SOD mimetic MnL4 on in vitro and in vivo oxaliplatin toxicity: Possible aid in chemotherapy induced neuropathy. Free Radic. Biol. Med. 2016, 93, 67-76. [CrossRef]

28. Cerles, O.; Benoit, E.; Chéreau, C.; Chouzenoux, S.; Morin, F.; Guillaumot, M.A.; Coriat, R.; Kavian, N.; Loussier, T.; Santulli, P.; et al. Niclosamide Inhibits Oxaliplatin Neurotoxicity while Improving Colorectal Cancer Therapeutic Response. Mol. Cancer Ther. 2017, 16, 300-311. [CrossRef]

29. Kim, S.T.; Chung, Y.H.; Lee, H.S.; Chung, S.J.; Lee, J.H.; Sohn, U.D.; Shin, Y.K.; Park, E.S.; Kim, H.C.; Bang, J.S.; et al. Protective effects of phosphatidylcholine on oxaliplatin-induced neuropathy in rats. Life Sci. 2015, 130, 81-87. [CrossRef]

30. Schwingel, T.E.; Klein, C.P.; Nicoletti, N.F.; Dora, C.L.; Hadrich, G.; Bica, C.G.; Lopes, T.G.; da Silva, V.D.; Morrone, F.B. Effects of the compounds resveratrol, rutin, quercetin, and quercetin nanoemulsion on oxaliplatin-induced hepatotoxicity and neurotoxicity in mice. Naunyn Schmiedebergs Arch. Pharmacol. 2014, 387, 837-848. [CrossRef]

31. Azevedo, M.I.; Pereira, A.F.; Nogueira, R.B.; Rolim, F.E.; Brito, G.A.; Wong, D.V.; Lima-Júnior, R.C.; de Albuquerque Ribeiro, R.; Vale, M.L. The antioxidant effects of the flavonoids rutin and quercetin inhibit oxaliplatin-induced chronic painful peripheral neuropathy. Mol. Pain 2013, 9, 53. [CrossRef] [PubMed]

32. Zanardelli, M.; Micheli, L.; Cinci, L.; Failli, P.; Ghelardini, C.; Di Cesare Mannelli, L. Oxaliplatin neurotoxicity involves peroxisome alterations. PPAR $\gamma$ agonism as preventive pharmacological approach. PLoS ONE 2014, 18, e102758. [CrossRef] [PubMed]

33. Areti, A.; Komirishetty, P.; Kalvala, A.K.; Nellaiappan, K.; Kumar, A. Rosmarinic Acid Mitigates Mitochondrial Dysfunction and Spinal Glial Activation in Oxaliplatin-induced Peripheral Neuropathy. Mol. Neurobiol. 2018, 55, 7463-7475. [CrossRef] [PubMed]

34. Di Cesare Mannelli, L.; Zanardelli, M.; Failli, P.; Ghelardini, C. Oxaliplatin-induced neuropathy: Oxidative stress as pathological mechanism. Prot. eff. silibinin. J. Pain. 2012, 13, 276-284. [CrossRef]

35. Toyama, S.; Shimoyama, N.; Szeto, H.H.; Schiller, P.W.; Shimoyama, M. Protective Effect of a Mitochondria-Targeted Peptide against the Development of Chemotherapy-Induced Peripheral Neuropathy in Mice. ACS Chem. Neurosci. 2018, 9, $1566-1571$. [CrossRef]

36. Toyama, S.; Shimoyama, N.; Ishida, Y.; Koyasu, T.; Szeto, H.H.; Shimoyama, M. Characterization of acute and chronic neuropathies induced by oxaliplatin in mice and differential effects of a novel mitochondria-targeted antioxidant on the neuropathies. Anesthesiology 2014, 120, 459-473. [CrossRef]

37. Yang, Y.; Luo, L.; Cai, X.; Fang, Y.; Wang, J.; Chen, G.; Yang, J.; Zhou, Q.; Sun, X.; Cheng, X.; et al. Nrf2 inhibits oxaliplatin-induced peripheral neuropathy via protection of mitochondrial function. Free Radic. Biol. Med. 2018, 120, 13-24. [CrossRef]

38. Micheli, L.; Mattoli, L.; Maidecchi, A.; Pacini, A.; Ghelardini, C.; Di Cesare Mannelli, L. Effect of Vitis vinifera hydroalcoholic extract against oxaliplatin neurotoxicity: In vitro and in vivo evidence. Sci. Rep. 2018, 8, 14364. [CrossRef]

39. Li, D.; Kim, W.; Shin, D.; Jung, Y.; Bae, H.; Kim, S.K. Preventive Effects of Bee Venom Derived Phospholipase A 2 on OxaliplatinInduced Neuropathic Pain in Mice. Toxins 2016, 8, 27. [CrossRef] 
40. Di Cesare Mannelli, L.; Pacini, A.; Micheli, L.; Tani, A.; Zanardelli, M.; Ghelardini, C. Glial role in oxaliplatin-induced neuropathic pain. Exp. Neurol. 2014, 261, 22-33. [CrossRef]

41. Cheng, X.; Huo, J.; Wang, D.; Cai, X.; Sun, X.; Lu, W.; Yang, Y.; Hu, C.; Wang, X.; Cao, P. Herbal Medicine AC591 Prevents Oxaliplatin-Induced Peripheral Neuropathy in Animal Model and Cancer Patients. Front. Pharmacol. 2017, 8, 344. [CrossRef] [PubMed]

42. Wan, C.F.; Zheng, L.L.; Liu, Y.; Yu, X. Houttuynia cordata Thunb reverses oxaliplatin-induced neuropathic pain in rat by regulating Th17/Treg balance. Am. J. Transl. Res. 2016, 8, 1609-1614. [PubMed]

43. Robinson, C.R.; Zhang, H.; Dougherty, P.M. Astrocytes, but not microglia, are activated in oxaliplatin and bortezomib-induced peripheral neuropathy in the rat. Neuroscience 2014, 274, 308-317. [CrossRef] [PubMed]

44. Duan, Z.; Su, Z.; Wang, H.; Pang, X. Involvement of pro-inflammation signal pathway in inhibitory effects of rapamycin on oxaliplatin-induced neuropathic pain. Mol. Pain 2018, 14, 1744806918769426. [CrossRef]

45. Egashira, N.; Hirakawa, S.; Kawashiri, T.; Yano, T.; Ikesue, H.; Oishi, R. Mexiletine reverses oxaliplatin-induced neuropathic pain in rats. J. Pharmacol. Sci. 2010, 112, 473-476. [CrossRef]

46. Zhao, M.; Nakamura, S.; Miyake, T.; So, K.; Shirakawa, H.; Tokuyama, S.; Narita, M.; Nakagawa, T.; Kaneko, S. Pharmacological characterization of standard analgesics on oxaliplatin-induced acute cold hypersensitivity in mice. J. Pharmacol. Sci. 2014, 124, 514-517. [CrossRef]

47. Rapacz, A.; Obniska, J.; Koczurkiewicz, P.; Wójcik-Pszczoła, K.; Siwek, A.; Gryboś, A.; Rybka, S.; Karcz, A.; Pękala, E.; Filipek, B. Antiallodynic and antihyperalgesic activity of new 3,3-diphenyl-propionamides with anticonvulsant activity in models of pain in mice. Eur. J. Pharmacol. 2018, 821, 39-48. [CrossRef]

48. Deuis, J.R.; Lim, Y.L.; Rodrigues de Sousa, S.; Lewis, R.J.; Alewood, P.F.; Cabot, P.J.; Vetter, I. Analgesic effects of clinically used compounds in novel mouse models of polyneuropathy induced by oxaliplatin and cisplatin. Neuro Oncol. 2014, 16, 1324-1332. [CrossRef]

49. Furgała-Wojas, A.; Kowalska, M.; Nowaczyk, A.; Fijałkowski, Ł.; Sałat, K. Comparison of Bromhexine and its Active MetaboliteAmbroxol as Potential Analgesics Reducing Oxaliplatin-Induced Neuropathic Pain—Pharmacodynamic and Molecular Docking Studies. Curr. Drug Metab. 2020, 21, 548-561. [CrossRef]

50. Lucarini, E.; Micheli, L.; Trallori, E.; Citi, V.; Martelli, A.; Testai, L.; De Nicola, G.R.; Iori, R.; Calderone, V.; Ghelardini, C.; et al. Effect of glucoraphanin and sulforaphane against chemotherapy-induced neuropathic pain: Kv7 potassium channels modulation by $\mathrm{H} 2 \mathrm{~S}$ release in vivo. Phytother. Res. 2018, 32, 2226-2234. [CrossRef]

51. Di Cesare Mannelli, L.; Lucarini, E.; Micheli, L.; Mosca, I.; Ambrosino, P.; Soldovieri, M.V.; Martelli, A.; Testai, L.; Taglialatela, M.; Calderone, V.; et al. Effects of natural and synthetic isothiocyanate-based H2S-releasers against chemotherapy-induced neuropathic pain: Role of Kv7 potassium channels. Neuropharmacology 2017, 121, 49-59. [CrossRef] [PubMed]

52. Poupon, L.; Lamoine, S.; Pereira, V.; Barriere, D.A.; Lolignier, S.; Giraudet, F.; Aissouni, Y.; Meleine, M.; Prival, L.; Richard, D.; et al. Targeting the TREK-1 potassium channel via riluzole to eliminate the neuropathic and depressive-like effects of oxaliplatin. Neuropharmacology 2018, 140, 43-61. [CrossRef] [PubMed]

53. Ohsawa, M.; Otake, S.; Murakami, T.; Yamamoto, S.; Makino, T.; Ono, H. Gabapentin prevents oxaliplatin-induced mechanical hyperalgesia in mice. J. Pharmacol. Sci. 2014, 125, 292-299. [CrossRef] [PubMed]

54. Aoki, M.; Kurauchi, Y.; Mori, A.; Nakahara, T.; Sakamoto, K.; Ishii, K. Comparison of the effects of single doses of elcatonin and pregabalin on oxaliplatin-induced cold and mechanical allodynia in rats. Biol. Pharm Bull. 2014, 37, 322-326. [CrossRef]

55. Potenzieri, A.; Riva, B.; Rigolio, R.; Chiorazzi, A.; Pozzi, E.; Ballarini, E.; Cavaletti, G.; Genazzani, A.A. Oxaliplatin-induced neuropathy occurs through impairment of haemoglobin proton buffering and is reversed by carbonic anhydrase inhibitors. Pain 2020, 161, 405-415. [CrossRef]

56. Andoh, T.; Mizoguchi, S.; Kuraishi, Y. Shakuyakukanzoto attenuates oxaliplatin-induced cold dysesthesia by inhibiting the expression of transient receptor potential melastatin 8 in mice. J. Tradit. Complement. Med. 2016, 7, 30-33. [CrossRef]

57. Mizuno, K.; Kono, T.; Suzuki, Y.; Miyagi, C.; Omiya, Y.; Miyano, K.; Kase, Y.; Uezono, Y. Goshajinkigan, a traditional Japanese medicine, prevents oxaliplatin-induced acute peripheral neuropathy by suppressing functional alteration of TRP channels in rat. J. Pharmacol. Sci. 2014, 125, 91-98. [CrossRef]

58. Kato, Y.; Tateai, Y.; Ohkubo, M.; Saito, Y.; Amagai, S.Y.; Kimura, Y.S.; Iimura, N.; Okada, M.; Matsumoto, A.; Mano, Y.; et al. Gosha-jinki-gan reduced oxaliplatin-induced hypersensitivity to cold sensation and its effect would be related to suppression of the expression of TRPM8 and TRPA1 in rats. Anticancer Drugs. 2014, 25, 39-43. [CrossRef]

59. Aoki, M.; Mori, A.; Nakahara, T.; Sakamoto, K.; Ishii, K. Effect of synthetic eel calcitonin, elcatonin, on cold and mechanical allodynia induced by oxaliplatin and paclitaxel in rats. Eur. J. Pharmacol. 2012, 696, 62-69. [CrossRef]

60. Kawashiri, T.; Egashira, N.; Kurobe, K.; Tsutsumi, K.; Yamashita, Y.; Ushio, S.; Yano, T.; Oishi, R. L type Ca ${ }^{2+}$ channel blockers prevent oxaliplatin-induced cold hyperalgesia and TRPM8 overexpression in rats. Mol. Pain 2012, 8, 7. [CrossRef]

61. Resta, F.; Micheli, L.; Laurino, A.; Spinelli, V.; Mello, T.; Sartiani, L.; Di Cesare Mannelli, L.; Cerbai, E.; Ghelardini, C.; Romanelli, M.N.; et al. Selective HCN1 block as a strategy to control oxaliplatin-induced neuropathy. Neuropharmacology 2018, 131, 403-413. [CrossRef] [PubMed]

62. Dini, L.; Del Lungo, M.; Resta, F.; Melchiorre, M.; Spinelli, V.; Di Cesare Mannelli, L.; Ghelardini, C.; Laurino, A.; Sartiani, L.; Coppini, R.; et al. Selective Blockade of HCN1/HCN2 Channels as a Potential Pharmacological Strategy against Pain. Front. Pharmacol. 2018, 9, 1252. [CrossRef] [PubMed] 
63. Micheli, L.; Di Cesare Mannelli, L.; Del Bello, F.; Giannella, M.; Piergentili, A.; Quaglia, W.; Carrino, D.; Pacini, A.; Ghelardini, C. The Use of the Selective Imidazoline I1 Receptor Agonist Carbophenyline as a Strategy for Neuropathic Pain Relief: Preclinical Evaluation in a Mouse Model of Oxaliplatin-Induced Neurotoxicity. Neurotherapeutics 2020, 17, 1005-1015. [CrossRef] [PubMed]

64. Yamamoto, S.; Ushio, S.; Egashira, N.; Kawashiri, T.; Mitsuyasu, S.; Higuchi, H.; Ozawa, N.; Masuguchi, K.; Ono, Y.; Masuda, S. Excessive spinal glutamate transmission is involved in oxaliplatin-induced mechanical allodynia: A possibility for riluzole as a prophylactic drug. Sci. Rep. 2017, 7, 9661. [CrossRef] [PubMed]

65. Fariello, R.G.; Ghelardini, C.; Di Cesare Mannelli, L.; Bonanno, G.; Pittaluga, A.; Milanese, M.; Misiano, P.; Farina, C. Broad spectrum and prolonged efficacy of dimiracetam in models of neuropathic pain. Neuropharmacology 2014, 81, 85-94. [CrossRef]

66. Wozniak, K.M.; Wu, Y.; Vornov, J.J.; Lapidus, R.; Rais, R.; Rojas, C.; Tsukamoto, T.; Slusher, B.S. The orally active glutamate carboxypeptidase II inhibitor E2072 exhibits sustained nerve exposure and attenuates peripheral neuropathy. J. Pharmacol. Exp. Ther. 2012, 343, 746-754. [CrossRef]

67. Zhou, H.H.; Zhang, L.; Zhang, H.X.; Xu, B.R.; Zhang, J.P.; Zhou, Y.J.; Qian, X.P.; Ge, W.H. Tat-HA-NR2B9c attenuate oxaliplatininduced neuropathic pain. Exp. Neurol. 2019, 311, 80-87. [CrossRef]

68. Liu, X.; Zhang, G.; Dong, L.; Wang, X.; Sun, H.; Shen, J.; Li, W.; Xu, J. Repeated administration of mirtazapine attenuates oxaliplatin-induced mechanical allodynia and spinal NR2B up-regulation in rats. Neurochem. Res. 2013, 38, 1973-1979. [CrossRef]

69. Mihara, Y.; Egashira, N.; Sada, H.; Kawashiri, T.; Ushio, S.; Yano, T.; Ikesue, H.; Oishi, R. Involvement of spinal NR2B-containing NMDA receptors in oxaliplatin-induced mechanical allodynia in rats. Mol. Pain 2011, 7, 8. [CrossRef]

70. Sada, H.; Egashira, N.; Ushio, S.; Kawashiri, T.; Shirahama, M.; Oishi, R. Repeated administration of amitriptyline reduces oxaliplatin-induced mechanical allodynia in rats. J. Pharmacol. Sci. 2012, 118, 547-551. [CrossRef]

71. Shirahama, M.; Ushio, S.; Egashira, N.; Yamamoto, S.; Sada, H.; Masuguchi, K.; Kawashiri, T.; Oishi, R. Inhibition of $\mathrm{Ca} 2+$ /calmodulin-dependent protein kinase II reverses oxaliplatin-induced mechanical allodynia in rats. Mol. Pain 2012, 8, 26. [CrossRef]

72. Ogihara, T.; Nakagawa, T.; Hayashi, M.; Koyanagi, M.; Yonezawa, A.; Omura, T.; Nakagawa, S.; Kitada, N.; Imai, S.; Matsubara, K. Improvement of peripheral vascular impairment by a phosphodiesterase type 5 inhibitor tadalafil prevents oxaliplatin-induced peripheral neuropathy in mice. J. Pharmacol. Sci. 2019, 141, 131-138. [CrossRef] [PubMed]

73. Johnston, I.N.; Tan, M.; Cao, J.; Matsos, A.; Forrest, D.R.L.; Si, E.; Fardell, J.E.; Hutchinson, M.R. Ibudilast reduces oxaliplatininduced tactile allodynia and cognitive impairments in rats. Behav. Brain Res. 2017, 334, 109-118. [CrossRef] [PubMed]

74. Pontes, R.B.; Lisboa, M.R.P.; Pereira, A.F.; Lino, J.A.; de Oliveira, F.F.B.; de Mesquita, A.K.V.; de Freitas Alves, B.W.; Lima-Júnior, R.C.P.; Vale, M.L. Involvement of Endothelin Receptors in Peripheral Sensory Neuropathy Induced by Oxaliplatin in Mice. Neurotox. Res. 2019, 36, 688-699. [CrossRef] [PubMed]

75. King, K.M.; Myers, A.M.; Soroka-Monzo, A.J.; Tuma, R.F.; Tallarida, R.J.; Walker, E.A.; Ward, S.J. Single and combined effects of $\Delta 9$-tetrahydrocannabinol and cannabidiol in a mouse model of chemotherapy-induced neuropathic pain. Br. J. Pharmacol. 2017, 174, 2832-2841. [CrossRef]

76. Gris, G.; Portillo-Salido, E.; Aubel, B.; Darbaky, Y.; Deseure, K.; Vela, J.M.; Merlos, M.; Zamanillo, D. The selective sigma-1 receptor antagonist E-52862,enuates neuropathic pain of different aetiology in rats. Sci. Rep. 2016, 6, 24591. [CrossRef]

77. Tomohisa, M.; Junpei, O.; Aki, M.; Masato, H.; Mika, F.; Kazumi, Y.; Teruo, H.; Tsutomu, S. Possible involvement of the Sigma-1 receptor chaperone in chemotherapeutic-induced neuropathic pain. Synapse 2015, 69, 526-532. [CrossRef]

78. Kanbara, T.; Nakamura, A.; Takasu, K.; Ogawa, K.; Shibasaki, M.; Mori, T.; Suzuki, T.; Hasegawa, M.; Sakaguchi, G.; Kanemasa, T. The contribution of Gi/o protein to opioid antinociception in an oxaliplatin-induced neuropathy rat model. J. Pharmacol. Sci. 2014, 126, 264-273. [CrossRef]

79. Bedini, A.; Di Cesare Mannelli, L.; Micheli, L.; Baiula, M.; Vaca, G.; De Marco, R.; Gentilucci, L.; Ghelardini, C.; Spampinato, S. Functional Selectivity and Antinociceptive Effects of a Novel KOPr Agonist. Front. Pharmacol. 2020, 11, 188. [CrossRef]

80. Shidahara, Y.; Ogawa, S.; Nakamura, M.; Nemoto, S.; Awaga, Y.; Takashima, M.; Hama, A.; Matsuda, A.; Takamatsu, H. Pharmacological comparison of a nonhuman primate and a rat model of oxaliplatin-induced neuropathic cold hypersensitivity. Pharmacol. Res. Perspect. 2016, 4, e00216. [CrossRef]

81. Furgała, A.; Sałat, R.; Sałat, K. Acute cold allodynia induced by oxaliplatin is attenuated by amitriptyline. Acta Neurobiol. Exp. (Wars) 2018, 78, 315-321. [CrossRef] [PubMed]

82. Yeo, J.H.; Yoon, S.Y.; Kwon, S.K.; Kim, S.J.; Lee, J.H.; Beitz, A.J.; Roh, D.H. Repetitive Acupuncture Point Treatment with Diluted Bee Venom Relieves Mechanical Allodynia and Restores Intraepidermal Nerve Fiber Loss in Oxaliplatin-Induced Neuropathic Mice. J. Pain 2016, 17, 298-309. [CrossRef] [PubMed]

83. Kim, W.; Kim, M.J.; Go, D.; Min, B.I.; Na, H.S.; Kim, S.K. Combined Effects of Bee Venom Acupuncture and Morphine on Oxaliplatin-Induced Neuropathic Pain in Mice. Toxins 2016, 8, 33. [CrossRef] [PubMed]

84. Lim, B.S.; Moon, H.J.; Li, D.X.; Gil, M.; Min, J.K.; Lee, G.; Bae, H.; Kim, S.K.; Min, B.I. Effect of bee venom acupuncture on oxaliplatin-induced cold allodynia in rats. Evid. Based Complement. Alternat. Med. 2013, 2013, 369324. [CrossRef]

85. Li, D.; Lee, Y.; Kim, W.; Lee, K.; Bae, H.; Kim, S.K. Analgesic Effects of Bee Venom Derived Phospholipase A(2) in a Mouse Model of Oxaliplatin-Induced Neuropathic Pain. Toxins 2015, 7, 2422-2434. [CrossRef]

86. Yeo, J.H.; Yoon, S.Y.; Kim, S.J.; Oh, S.B.; Lee, J.H.; Beitz, A.J.; Roh, D.H. Clonidine, an alpha-2 adrenoceptor agonist relieves mechanical allodynia in oxaliplatin-induced neuropathic mice; potentiation by spinal p38 MAPK inhibition without motor dysfunction and hypotension. Int. J. Cancer. 2016, 138, 2466-2476. [CrossRef] 
87. Kim, W.; Chung, Y.; Choi, S.; Min, B.I.; Kim, S.K. Duloxetine Protects against Oxaliplatin-Induced Neuropathic Pain and Spinal Neuron Hyperexcitability in Rodents. Int. J. Mol. Sci. 2017, 18, 2626. [CrossRef]

88. Balayssac, D.; Ling, B.; Ferrier, J.; Pereira, B.; Eschalier, A.; Authier, N. Assessment of thermal sensitivity in rats using the thermal place preference test: Description and application in the study of oxaliplatin-induced acute thermal hypersensitivity and inflammatory pain models. Behav. Pharmacol. 2014, 25, 99-111. [CrossRef]

89. Baptista-de-Souza, D.; Di Cesare Mannelli, L.; Zanardelli, M.; Micheli, L.; Nunes-de-Souza, R.L.; Canto-de-Souza, A.; Ghelardini, C. Serotonergic modulation in neuropathy induced by oxaliplatin: Effect on the 5HT2C receptor. Eur. J. Pharmacol. 2014, 735, 141-149. [CrossRef]

90. Choi, S.; Chae, H.K.; Heo, H.; Hahm, D.H.; Kim, W.; Kim, S.K. Analgesic Effect of Melittin on Oxaliplatin-Induced Peripheral Neuropathy in Rats. Toxins 2019, 11, 396. [CrossRef]

91. Sałat, K.; Kołaczkowski, M.; Furgała, A.; Rojek, A.; Śniecikowska, J.; Varney, M.A.; Newman-Tancredi, A. Antinociceptive, antiallodynic and antihyperalgesic effects of the 5-HT1A receptor selective agonist, NLX-112 in mouse models of pain. Neuropharmacology 2017, 125, 181-188. [CrossRef] [PubMed]

92. Yoon, S.Y.; Lee, J.Y.; Roh, D.H.; Oh, S.B. Pharmacopuncture With Scolopendra subspinipes Suppresses Mechanical Allodynia in Oxaliplatin-Induced Neuropathic Mice and Potentiates Clonidine-induced Anti-allodynia Without Hypotension or Motor Impairment. J. Pain 2018, 19, 1157-1168. [CrossRef] [PubMed]

93. Andoh, T.; Sakamoto, A.; Kuraishi, Y. 5-HT1A receptor agonists, xaliproden and tandospirone, inhibit the increase in the number of cutaneous mast cells involved in the exacerbation of mechanical allodynia in oxaliplatin-treated mice. J. Pharmacol. Sci. 2016, 131, 284-287. [CrossRef] [PubMed]

94. Micov, A.M.; Tomić, M.A.; Todorović, M.B.; Vuković, M.J.; Pecikoza, U.B.; Jasnic, N.I.; Djordjevic, J.D.; Stepanović-Petrović, R.M. Vortioxetine reduces pain hypersensitivity and associated depression-like behavior in mice with oxaliplatin-induced neuropathy. Prog. Neuropsychopharmacol. Biol. Psychiatry 2020, 103, 109975. [CrossRef] [PubMed]

95. Kanat, O.; Bagdas, D.; Ozboluk, H.Y.; Gurun, M.S. Preclinical evidence for the antihyperalgesic activity of CDP-choline in oxaliplatin-induced neuropathic pain. J. BUON 2013, 18, 1012-1018, Erratum in: J BUON 2014, 19, 323. Kanat, D [corrected to Kanat, O]. [PubMed]

96. Di Cesare Mannelli, L.; Pacini, A.; Matera, C.; Zanardelli, M.; Mello, T.; De Amici, M.; Dallanoce, C.; Ghelardini, C. Involvement of $\alpha 7 \mathrm{nAChR}$ subtype in rat oxaliplatin-induced neuropathy: Effects of selective activation. Neuropharmacology 2014, 79, 37-48. [CrossRef]

97. Wang, H.; Li, X.; Zhangsun, D.; Yu, G.; Su, R.; Luo, S. The $\alpha 9 \alpha 10$ Nicotinic Acetylcholine Receptor Antagonist $\alpha$ O-Conotoxin GeXIVA[1,2] Alleviates and Reverses Chemotherapy-Induced Neuropathic Pain. Mar. Drugs 2019, 17, 265. [CrossRef]

98. Pacini, A.; Micheli, L.; Maresca, M.; Branca, J.J.; McIntosh, J.M.; Ghelardini, C.; Di Cesare Mannelli, L. The $\alpha 9 \alpha 10$ nicotinic receptor antagonist $\alpha$-conotoxin RgIA prevents neuropathic pain induced by oxaliplatin treatment. Exp. Neurol. 2016, 282, 37-48. [CrossRef]

99. Huang, K.M.; Leblanc, A.F.; Uddin, M.E.; Kim, J.Y.; Chen, M.; Eisenmann, E.D.; Gibson, A.A.; Li, Y.; Hong, K.W.; DiGiacomo, D.; et al. Neuronal uptake transporters contribute to oxaliplatin neurotoxicity in mice. J. Clin. Investig. 2020, 130, 4601-4606. [CrossRef]

100. Nishida, K.; Takeuchi, K.; Hosoda, A.; Sugano, S.; Morisaki, E.; Ohishi, A.; Nagasawa, K. Ergothioneine ameliorates oxaliplatininduced peripheral neuropathy in rats. Life Sci. 2018, 207, 516-524. [CrossRef]

101. Toyama, S.; Shimoyama, N.; Shimoyama, M. The analgesic effect of orexin-A in a murine model of chemotherapy-induced neuropathic pain. Neuropeptides 2017, 61, 95-100. [CrossRef] [PubMed]

102. Chaumette, T.; Chapuy, E.; Berrocoso, E.; Llorca-Torralba, M.; Bravo, L.; Mico, J.A.; Chalus, M.; Eschalier, A.; Ardid, D.; Marchand, F.; et al. Effects of S 38093, an antagonist/inverse agonist of histamine H3 receptors, in models of neuropathic pain in rats. Eur. J. Pain. 2018, 22, 127-141. [CrossRef] [PubMed]

103. Tsubaki, M.; Takeda, T.; Matsumoto, M.; Kato, N.; Asano, R.T.; Imano, M.; Satou, T.; Nishida, S. Trametinib suppresses chemotherapy-induced cold and mechanical allodynia via inhibition of extracellular-regulated protein kinase $1 / 2$ activation. Am. J. Cancer Res. 2018, 8, 1239-1248. [PubMed]

104. Tsubaki, M.; Takeda, T.; Tani, T.; Shimaoka, H.; Suzuyama, N.; Sakamoto, K.; Fujita, A.; Ogawa, N.; Itoh, T.; Imano, M.; et al. PKC/MEK inhibitors suppress oxaliplatin-induced neuropathy and potentiate the antitumor effects. Int. J. Cancer 2015, 137, 243-250. [CrossRef] [PubMed]

105. Janes, K.; Little, J.W.; Li, C.; Bryant, L.; Chen, C.; Chen, Z.; Kamocki, K.; Doyle, T.; Snider, A.; Esposito, E.; et al. The development and maintenance of paclitaxel-induced neuropathic pain require activation of the sphingosine 1-phosphate receptor subtype 1. J. Biol. Chem. 2014, 289, 21082-21097. [CrossRef] [PubMed]

106. Minami, T.; Takeda, M.; Sata, M.; Kato, H.; Yano, K.; Sakai, T.; Tsujita, R.; Kawasaki, K.; Ito, A. Thrombomodulin alfa prevents oxaliplatin-induced neuropathic symptoms through activation of thrombin-activatable fibrinolysis inhibitor and protein $\mathrm{C}$ without affecting anti-tumor activity. Eur. J. Pharmacol. 2020, 880, 173196. [CrossRef]

107. Tsubota, M.; Fukuda, R.; Hayashi, Y.; Miyazaki, T.; Ueda, S.; Yamashita, R.; Koike, N.; Sekiguchi, F.; Wake, H.; Wakatsuki, S.; et al. Role of non-macrophage cell-derived HMGB1 in oxaliplatin-induced peripheral neuropathy and its prevention by the thrombin/thrombomodulin system in rodents: Negative impact of anticoagulants. J. NeuroInflamm. 2019, 16, 199. [CrossRef] 
108. Di Cesare Mannelli, L.; Tenci, B.; Micheli, L.; Vona, A.; Corti, F.; Zanardelli, M.; Lapucci, A.; Clemente, A.M.; Failli, P.; Ghelardini, C. Adipose-derived stem cells decrease pain in a rat model of oxaliplatin-induced neuropathy: Role of VEGF-A modulation. Neuropharmacology 2018, 131, 166-175. [CrossRef]

109. Miguel, C.A.; Raggio, M.C.; Villar, M.J.; Gonzalez, S.L.; Coronel, M.F. Anti-allodynic and anti-inflammatory effects of $17 \alpha-$ hydroxyprogesterone caproate in oxaliplatin-induced peripheral neuropathy. J. Peripher. Nerv. Syst. 2019, 24, 100-110. [CrossRef]

110. Taleb, O.; Bouzobra, F.; Tekin-Pala, H.; Meyer, L.; Mensah-Nyagan, A.G.; Patte-Mensah, C. Behavioral and electromyographic assessment of oxaliplatin-induced motor dysfunctions: Evidence for a therapeutic effect of allopregnanolone. Behav. Brain Res. 2017, 320, 440-449. [CrossRef]

111. Shigematsu, N.; Kawashiri, T.; Kobayashi, D.; Shimizu, S.; Mine, K.; Hiromoto, S.; Uchida, M.; Egashira, N.; Shimazoe, T. Neuroprotective effect of alogliptin on oxaliplatin-induced peripheral neuropathy in vivo and in vitro. Sci. Rep. 2020, 10, 6734. [CrossRef] [PubMed]

112. Yi, J.M.; Shin, S.; Kim, N.S.; Bang, O.S. Neuroprotective Effects of an Aqueous Extract of Forsythia viridissima and Its Major Constituents on Oxaliplatin-Induced Peripheral Neuropathy. Molecules 2019, 24, 1177. [CrossRef] [PubMed]

113. Yi, J.M.; Shin, S.; Kim, N.S.; Bang, O.S. Ameliorative effects of aqueous extract of Forsythiae suspensa fruits on oxaliplatin-induced neurotoxicity in vitro and in vivo. BMC Complement. Altern. Med. 2019, 19, 339. [CrossRef]

114. Cho, E.S.; Yi, J.M.; Park, J.S.; Lee, Y.J.; Lim, C.J.; Bang, O.S.; Kim, N.S. Aqueous extract of Lithospermi radix attenuates oxaliplatin-induced neurotoxicity in both in vitro and in vivo models. BMC Complement. Altern. Med. 2016, 16, 419. [CrossRef] [PubMed]

115. Sałat, K.; Furgała, A.; Sałat, R. Interventional and preventive effects of aripiprazole and ceftriaxone used alone or in combination on oxaliplatin-induced tactile and cold allodynia in mice. Biomed. Pharmacother. 2019, 111, 882-890. [CrossRef] [PubMed]

116. Di Cesare Mannelli, L.; Pacini, A.; Micheli, L.; Femia, A.P.; Maresca, M.; Zanardelli, M.; Vannacci, A.; Gallo, E.; Bilia, A.R.; Caderni, G.; et al. Astragali radix: Could it be an adjuvant for oxaliplatin-induced neuropathy? Sci. Rep. 2017, 7, 42021. [CrossRef]

117. Cerles, O.; Gonçalves, T.C.; Chouzenoux, S.; Benoit, E.; Schmitt, A.; Bennett Saidu, N.E.; Kavian, N.; Chéreau, C.; Gobeaux, C.; Weill, B.; et al. Preventive action of benztropine on platinum-induced peripheral neuropathies and tumor growth. Acta Neuropathol. Commun. 2019, 7, 9. [CrossRef] [PubMed]

118. Kim, C.; Lee, J.H.; Kim, W.; Li, D.; Kim, Y.; Lee, K.; Kim, S.K. The Suppressive Effects of Cinnamomi Cortex and Its Phytocompound Coumarin on Oxaliplatin-Induced Neuropathic Cold Allodynia in Rats. Molecules 2016, 21, 1253. [CrossRef] [PubMed]

119. Di Cesare Mannelli, L.; Piccolo, M.; Maione, F.; Ferraro, M.G.; Irace, C.; De Feo, V.; Ghelardini, C.; Mascolo, N. Tanshinones from Salvia miltiorrhiza Bunge revert chemotherapy-induced neuropathic pain and reduce glioblastoma cells malignancy. Biomed. Pharmacother. 2018, 105, 1042-1049. [CrossRef]

120. Al Moundhri, M.S.; Al-Salam, S.; Al Mahrouqee, A.; Beegam, S.; Ali, B.H. The effect of curcumin on oxaliplatin and cisplatin neurotoxicity in rats: Some behavioral, biochemical, and histopathological studies. J. Med. Toxicol. 2013, 9, 25-33. [CrossRef]

121. Fujita, S.; Ushio, S.; Ozawa, N.; Masuguchi, K.; Kawashiri, T.; Oishi, R.; Egashira, N. Exenatide Facilitates Recovery from Oxaliplatin-Induced Peripheral Neuropathy in Rats. PLoS ONE 2015, 10, e0141921. [CrossRef] [PubMed]

122. Yamamoto, S.; Yamashita, T.; Ito, M.; Caaveiro, J.M.M.; Egashira, N.; Tozaki-Saitoh, H.; Tsuda, M. New pharmacological effect of fulvestrant to prevent oxaliplatin-induced neurodegeneration and mechanical allodynia in rats. Int. J. Cancer 2019, 145, $2107-2113$. [CrossRef]

123. Mizuno, K.; Shibata, K.; Komatsu, R.; Omiya, Y.; Kase, Y.; Koizumi, S. An effective therapeutic approach for oxaliplatin-induced peripheral neuropathy using a combination therapy with goshajinkigan and bushi. Cancer Biol. Ther. 2016, 17, 1206-1212. [CrossRef] [PubMed]

124. Ushio, S.; Egashira, N.; Sada, H.; Kawashiri, T.; Shirahama, M.; Masuguchi, K.; Oishi, R. Goshajinkigan reduces oxaliplatininduced peripheral neuropathy without affecting anti-tumour efficacy in rodents. Eur. J. Cancer. 2012, 48, 1407-1413. [CrossRef] [PubMed]

125. Yang, Y.; Hu, L.; Wang, C.; Yang, X.; Song, L.; Jiang, C.; Li, Y.; Li, T.; Liu, W.T.; Feng, J. p38/TF/HIF- $\alpha$ Signaling Pathway Participates in the Progression of CIPN in Mice. Biomed Res. Int. 2019, 2019, 5347804. [CrossRef]

126. Chiorazzi, A.; Wozniak, K.M.; Rais, R.; Wu, Y.; Gadiano, A.J.; Farah, M.H.; Liu, Y.; Canta, A.; Alberti, P.; Rodriguez-Menendez, V.; et al. Ghrelin agonist HM01 attenuates chemotherapy-induced neurotoxicity in rodent models. Eur. J. Pharmacol. 2018, 840, 89-103. [CrossRef]

127. Areti, A.; Komirishetty, P.; Akuthota, M.; Malik, R.A.; Kumar, A. Melatonin prevents mitochondrial dysfunction and promotes neuroprotection by inducing autophagy during oxaliplatin-evoked peripheral neuropathy. J. Pineal. Res. 2017, 62. [CrossRef]

128. Martinez, N.W.; Sánchez, A.; Diaz, P.; Broekhuizen, R.; Godoy, J.; Mondaca, S.; Catenaccio, A.; Macanas, P.; Nervi, B.; Calvo, M.; et al. Metformin protects from oxaliplatin induced peripheral neuropathy in rats. Neurobiol. Pain 2020, $8,100048$. [CrossRef]

129. Pereira, A.F.; Pereira, L.M.S.; Silva, C.M.P.; Freitas Alves, B.W.; Barbosa, J.S.; Pinto, F.M.M.; Pereira, A.C.; Silva, K.O.; Pontes, R.B.; Alencar, N.M.N.; et al. Metformin reduces c-Fos and ATF3 expression in the dorsal root ganglia and protects against oxaliplatininduced peripheral sensory neuropathy in mice. Neurosci. Lett. 2019, 709, 134378. [CrossRef]

130. Masuguchi, K.; Watanabe, H.; Kawashiri, T.; Ushio, S.; Ozawa, N.; Morita, H.; Oishi, R.; Egashira, N. Neurotropin ${ }^{\circledR}$ relieves oxaliplatin-induced neuropathy via Gi protein-coupled receptors in the monoaminergic descending pain inhibitory system. Life Sci. 2014, 98, 49-54. [CrossRef] 
131. Kawashiri, T.; Egashira, N.; Watanabe, H.; Ikegami, Y.; Hirakawa, S.; Mihara, Y.; Yano, T.; Ikesue, H.; Oishi, R. Prevention of oxaliplatin-induced mechanical allodynia and neurodegeneration by neurotropin in the rat model. Eur. J. Pain 2011, 15, 344-350. [CrossRef] [PubMed]

132. Suzuki, T.; Yamamoto, A.; Ohsawa, M.; Motoo, Y.; Mizukami, H.; Makino, T. Effect of ninjin'yoeito and ginseng extracts on oxaliplatin-induced neuropathies in mice. J. Nat. Med. 2017, 71, 757-764. [CrossRef] [PubMed]

133. Di Cesare Mannelli, L.; Pacini, A.; Corti, F.; Boccella, S.; Luongo, L.; Esposito, E.; Cuzzocrea, S.; Maione, S.; Calignano, A.; Ghelardini, C. Antineuropathic profile of N-palmitoylethanolamine in a rat model of oxaliplatin-induced neurotoxicity. PLoS ONE 2015, 10, e0128080. [CrossRef] [PubMed]

134. Suzuki, T.; Miyamoto, K.; Yokoyama, N.; Sugi, M.; Kagioka, A.; Kitao, Y.; Adachi, T.; Ohsawa, M.; Mizukami, H.; Makino, T. Processed aconite root and its active ingredient neoline may alleviate oxaliplatin-induced peripheral neuropathic pain. J. Ethnopharmacol. 2016, 186, 44-52. [CrossRef] [PubMed]

135. Aoki, M.; Mori, A.; Nakahara, T.; Sakamoto, K.; Ishii, K. Salmon calcitonin reduces oxaliplatin-induced cold and mechanical allodynia in rats. Biol. Pharm. Bull. 2013, 36, 326-329. [CrossRef]

136. Cheng, W.; Xiang, W.; Wang, S.; Xu, K. Tanshinone IIA ameliorates oxaliplatin-induced neurotoxicity via mitochondrial protection and autophagy promotion. Am. J. Transl. Res. 2019, 11, 3140-3149.

137. Alberti, P.; Canta, A.; Chiorazzi, A.; Fumagalli, G.; Meregalli, C.; Monza, L.; Pozzi, E.; Ballarini, E.; Rodriguez-Menendez, V.; Oggioni, N.; et al. Topiramate prevents oxaliplatin-related axonal hyperexcitability and oxaliplatin induced peripheral neurotoxicity. Neuropharmacology 2020, 164, 107905. [CrossRef]

138. Tenci, B.; Di Cesare Mannelli, L.; Maresca, M.; Micheli, L.; Pieraccini, G.; Mulinacci, N.; Ghelardini, C. Effects of a water extract of Lepidium meyenii root in different models of persistent pain in rats. Z. Naturforsch. C J. Biosci. 2017, 72, 449-457. [CrossRef]

139. Deng, B.; Jia, L.; Pan, L.; Song, A.; Wang, Y.; Tan, H.; Xiang, Q.; Yu, L.; Ke, D. Wen-Luo-Tong Prevents Glial Activation and Nociceptive Sensitization in a Rat Model of Oxaliplatin-Induced Neuropathic Pain. Evid. Based Complement. Alternat. Med. 2016, 2016, 3629489. [CrossRef]

140. McQuade, R.M.; Carbone, S.E.; Stojanovska, V.; Rahman, A.; Gwynne, R.M.; Robinson, A.M.; Goodman, C.A.; Bornstein, J.C.; Nurgali, K. Role of oxidative stress in oxaliplatin-induced enteric neuropathy and colonic dysmotility in mice. Br. J. Pharmacol. 2016, 173, 3502-3521. [CrossRef]

141. Di Cesare Mannelli, L.; Zanardelli, M.; Failli, P.; Ghelardini, C. Oxaliplatin-induced oxidative stress in nervous system-derived cellular models: Could it correlate with in vivo neuropathy? Free Radic. Biol. Med. 2013, 61, 143-150. [CrossRef] [PubMed]

142. Adelsberger, H.; Quasthoff, S.; Grosskreutz, J.; Lepier, A.; Eckel, F.; Lersch, C. The chemotherapeutic oxaliplatin alters voltagegated $\mathrm{Na}(+)$ channel kinetics on rat sensory neurons. Eur. J. Pharmacol. 2000, 406, 25-32. [CrossRef]

143. Grolleau, F.; Gamelin, L.; Boisdron-Celle, M.; Lapied, B.; Pelhate, M.; Gamelin, E. A possible explanation for a neurotoxic effect of the anticancer agent oxaliplatin on neuronal voltage-gated sodium channels. J. Neurophysiol. 2001, 85, 2293-2297. [CrossRef] [PubMed]

144. Gauchan, P.; Andoh, T.; Kato, A.; Kuraishi, Y. Involvement of increased expression of transient receptor potential melastatin 8 in oxaliplatin-induced cold allodynia in mice. Neurosci. Lett. 2009, 458, 93-95. [CrossRef] [PubMed]

145. Ta, L.E.; Bieber, A.J.; Carlton, S.M.; Loprinzi, C.L.; Low, P.A.; Windebank, A.J. Transient Receptor Potential Vanilloid 1 is essential for cisplatin-induced heat hyperalgesia in mice. Mol. Pain 2010, 6, 15. [CrossRef] [PubMed]

146. Descoeur, J.; Pereira, V.; Pizzoccaro, A.; Francois, A.; Ling, B.; Maffre, V.; Couette, B.; Busserolles, J.; Courteix, C.; Noel, J.; et al. Oxaliplatin-induced cold hypersensitivity is due to remodelling of ion channel expression in nociceptors. EMBO Mol. Med. 2011, 3, 266-278. [CrossRef] [PubMed]

147. Yoshimura, M.; Furue, H. Mechanisms for the anti-nociceptive actions of the descending noradrenergic and serotonergic systems in the spinal cord. J. Pharmacol. Sci. 2006, 101, 107-117. [CrossRef]

148. Smith, E.M.; Pang, H.; Cirrincione, C.; Fleishman, S.; Paskett, E.D.; Ahles, T.; Bressler, L.R.; Fadul, C.E.; Knox, C.; Le-Lindqwister, N.; et al. Alliance for Clinical Trials in Oncology. Effect of duloxetine on pain, function, and quality of life among patients with chemotherapy-induced painful peripheral neuropathy: A randomized clinical trial. JAMA 2013, 309, 1359-1367. [CrossRef]

149. Grothey, A.; Nikcevich, D.A.; Sloan, J.A.; Kugler, J.W.; Silberstein, P.T.; Dentchev, T.; Wender, D.B.; Novotny, P.J.; Chitaley, U.; Alberts, S.R.; et al. Intravenous calcium and magnesium for oxaliplatin-induced sensory neurotoxicity in adjuvant colon cancer: NCCTG N04C7. J. Clin. Oncol. 2011, 29, 421-427. [CrossRef]

150. Grothey, A.; Hart, L.L.; Rowland, K.M.; Ansari, R.H.; Alberts, S.R.; Chowhan, N.M.; Hochster, H.S. Intermittent oxaliplatin (oxali) administration and time-to-treatment-failure (TTF) in metastatic colorectal cancer (mCRC): Final results of the phase III CONcePT trial. J. Clin. Oncol. 2008, 26, 4010. [CrossRef]

151. Loprinzi, C.L.; Qin, R.; Dakhil, S.R.; Fehrenbacher, L.; Flynn, K.A.; Atherton, P.; Seisler, D.; Qamar, R.; Lewis, G.C.; Grothey, A. Phase III randomized, placebo-controlled, double-blind study of intravenous calcium and magnesium to prevent oxaliplatininduced sensory neurotoxicity (N08CB/Alliance). J. Clin. Oncol. 2014, 32, 997-1005. [CrossRef] [PubMed]

152. Han, C.H.; Khwaounjoo, P.; Kilfoyle, D.H.; Hill, A.; McKeage, M.J. Phase I drug-interaction study of effects of calcium and magnesium infusions on oxaliplatin pharmacokinetics and acute neurotoxicity in colorectal cancer patients. BMC Cancer 2013, 13, 495. [CrossRef] [PubMed]

153. Jordan, B.; Jahn, F.; Beckmann, J.; Unverzagt, S.; Müller-Tidow, C.; Jordan, K. Calcium and Magnesium Infusions for the Prevention of Oxaliplatin-Induced Peripheral Neurotoxicity: A Systematic Review. Oncology 2016, 90, 299-306. [CrossRef] [PubMed] 
154. Nishioka, M.; Shimada, M.; Kurita, N.; Iwata, T.; Morimoto, S.; Yoshikawa, K.; Higashijima, J.; Miyatani, T.; Kono, T. The Kampo medicine, Goshajinkigan, prevents neuropathy in patients treated by FOLFOX regimen. Int. J. Clin. Oncol. 2011, 16, 322-327. [CrossRef] [PubMed]

155. Kono, T.; Hata, T.; Morita, S.; Munemoto, Y.; Matsui, T.; Kojima, H.; Takemoto, H.; Fukunaga, M.; Nagata, N.; Shimada, M.; et al. Goshajinkigan oxaliplatin neurotoxicity evaluation (GONE): A phase 2, multicenter, randomized, double-blind, placebocontrolled trial of goshajinkigan to prevent oxaliplatin-induced neuropathy. Cancer Chemother. Pharmacol. 2013, 72, 1283-1290. [CrossRef]

156. Oki, E.; Emi, Y.; Kojima, H.; Higashijima, J.; Kato, T.; Miyake, Y.; Kon, M.; Ogata, Y.; Takahashi, K.; Ishida, H.; et al. Preventive effect of Goshajinkigan on peripheral neurotoxicity of FOLFOX therapy (GENIUS trial): A placebo-controlled, double-blind, randomized phase III study. Int. J. Clin. Oncol. 2015, 20, 767-775. [CrossRef]

157. Guo, Y.; Jones, D.; Palmer, J.L.; Forman, A.; Dakhil, S.R.; Velasco, M.R.; Weiss, M.; Gilman, P.; Mills, G.M.; Noga, S.J.; et al. Oral alpha-lipoic acid to prevent chemotherapy-induced peripheral neuropathy: A randomized, double-blind, placebo-controlled trial. Support. Care Cancer 2014, 22, 1223-1231. [CrossRef]

158. Salehi, Z.; Roayaei, M. Effect of Vitamin E on Oxaliplatin-induced Peripheral Neuropathy Prevention: A Randomized Controlled Trial. Int. J. Prev. Med. 2015, 6, 104. [CrossRef]

159. Huang, H.; He, M.; Liu, L.; Huang, L. Vitamin E does not decrease the incidence of chemotherapy-induced peripheral neuropathy: A meta-analysis. Contemp. Oncol. 2016, 20, 237. [CrossRef]

160. Cascinu, S.; Catalano, V.; Cordella, L.; Labianca, R.; Giordani, P.; Baldelli, A.M.; Beretta, G.D.; Ubiali, E.; Catalano, G. Neuroprotective effect of reduced glutathione on oxaliplatin-based chemotherapy in advanced colorectal cancer: A randomized, double-blind, placebo-controlled trial. J. Clin. Oncol. 2002, 20, 3478-3483. [CrossRef]

161. Glimelius, B.; Manojlovic, N.; Pfeiffer, P.; Mosidze, B.; Kurteva, G.; Karlberg, M.; Mahalingam, D.; Buhl Jensen, P.; Kowalski, J.; Bengtson, M.; et al. Persistent prevention of oxaliplatin-induced peripheral neuropathy using calmangafodipir (PledOx $\left.{ }^{\circledR}\right)$ : A placebo-controlled randomised phase II study (PLIANT). Acta Oncol. 2018, 57, 393-402. [CrossRef] [PubMed]

162. de Andrade, D.C.; Jacobsen Teixeira, M.; Galhardoni, R.; Ferreira, K.S.L.; Braz Mileno, P.; Scisci, N.; Zandonai, A.; Teixeira, W.G.J.; Saragiotto, D.F.; Silva, V. Pregabalin for the Prevention of Oxaliplatin-Induced Painful Neuropathy: A Randomized, Double-Blind Trial. Oncologist 2017, 22, 1154. [CrossRef] [PubMed]

163. Wang, X.S.; Shi, Q.; Bhadkamkar, N.A.; Cleeland, C.S.; Garcia-Gonzalez, A.; Aguilar, J.R.; Heijnen, C.; Eng, C. Minocycline for Symptom Reduction During Oxaliplatin-Based Chemotherapy for Colorectal Cancer: A Phase II Randomized Clinical Trial. J. Pain Symptom. Manag. 2019, 58, 662-671. [CrossRef] [PubMed] 